\title{
Sea-ice properties and nutrient concentration as drivers of the taxonomic and trophic structure of high-Arctic protist and metazoan communities
}

\author{
Hauke Flores ${ }^{1,2}\left(\right.$ D $\cdot$ Carmen David $^{1,2,3} \cdot$ Julia Ehrlich $^{1,2} \cdot$ Kristin Hardge $^{1} \cdot$ Doreen Kohlbach $^{1,2} \cdot$ Benjamin A. Lange $^{1,2,4}$. \\ Barbara Niehoff ${ }^{1} \cdot$ Eva-Maria Nöthig ${ }^{1} \cdot$ Ilka Peeken $^{1} \cdot$ Katja Metfies $^{1,5}$
}

Received: 10 January 2019 / Revised: 14 June 2019 / Accepted: 18 June 2019 / Published online: 28 June 2019

(c) Springer-Verlag GmbH Germany, part of Springer Nature 2019

\begin{abstract}
In the Arctic Ocean, sea-ice decline will significantly change the structure of biological communities. At the same time, changing nutrient dynamics can have similarly strong and potentially interacting effects. To investigate the response of the taxonomic and trophic structure of planktonic and ice-associated communities to varying sea-ice properties and nutrient concentrations, we analysed four different communities sampled in the Eurasian Basin in summer 2012: (1) protists and (2) metazoans from the under-ice habitat, and (3) protists and (4) metazoans from the epipelagic habitat. The taxonomic composition of protist communities was characterised with $18 \mathrm{~S}$ meta-barcoding. The taxonomic composition of metazoan communities was determined based on morphology. The analysis of environmental parameters identified (i) a 'shelf-influenced' regime with melting sea ice, high-silicate concentrations and low $\mathrm{NO}_{x}$ (nitrate + nitrite) concentrations; (ii) a 'Polar' regime with low silicate concentrations and low $\mathrm{NO}_{x}$ concentrations; and (iii) an 'Atlantic' regime with low silicate concentrations and high $\mathrm{NO}_{x}$ concentrations. Multivariate analyses of combined bio-environmental datasets showed that taxonomic community structure primarily responded to the variability of sea-ice properties and hydrography across all four communities. Trophic community structure, however, responded significantly to $\mathrm{NO}_{x}$ concentrations. In three of the four communities, the most heterotrophic trophic group significantly dominated in the $\mathrm{NO}_{x}$-poor shelf-influenced and Polar regimes compared to the $\mathrm{NO}_{x}$-rich Atlantic regime. The more heterotrophic, $\mathrm{NO}_{x}$-poor regimes were associated with lower productivity and carbon export than the $\mathrm{NO}_{x}$-rich Atlantic regime. For modelling future Arctic ecosystems, it is important to consider that taxonomic diversity can respond to different drivers than trophic diversity.
\end{abstract}

Keywords Arctic Ocean $\cdot$ Sea ice $\cdot$ Community structure $\cdot$ Protists $\cdot$ Zooplankton $\cdot$ Under-ice fauna $\cdot$ Nutrients $\cdot$ Trophic ecology

\section{Introduction}

The Arctic Ocean has been experiencing a rapid decline in sea-ice volume (Kwok and Rothrock 2009; Laxon et al. 2013) and sea-ice extent over the past two decades (Serreze

Electronic supplementary material The online version of this article (https://doi.org/10.1007/s00300-019-02526-z) contains et al. 2007; Stroeve et al. 2012; Simmonds 2015). Model

supplementary material, which is available to authorized users.

Hauke Flores

hauke.flores@awi.de

1 Section Polar Biological Oceanography, Alfred Wegener Institut Helmholtz-Zentrum für Polar- und Meeresforschung, Bremerhaven, Germany

2 Centre for Natural History (CeNak), University of Hamburg, Zoological Museum, Hamburg, Germany
3 Institut Français de Recherche Pour l'Exploitation de la Mer (Ifremer), Plouzané, France

4 Fisheries and Oceans Canada, Freshwater Institute, Winnipeg, MB, Canada

5 Helmholtz Institute for Functional Marine Biodiversity (HIFMB), Oldenburg, Germany 
simulations have indicated that an ice-free Arctic Ocean during summer is likely to occur by the mid of the twentyfirst century (Wang and Overland 2009; Stroeve et al. 2012). In the water column, significant environmental changes are expected to occur, such as an increase in surface water temperatures, changing circulation patterns, increased ocean acidification, enhanced stratification, and nutrient limitation (IPCC 2014). These changes will profoundly impact on ecosystem structure and function, such as carbon and nutrient cycling, carbon export, and availability of marineliving resources. Studies on Arctic plankton communities have demonstrated ongoing change in community composition and in the distribution of ecological key species related to ocean warming and sea ice decline (e.g. Bluhm et al. 2011; Wassmann 2011; Wassmann et al. 2011; Kraft et al. 2013; Nöthig et al. 2015; Hardge et al. 2017a, b). Seaice decline has been linked to enhanced pelagic primary production (Arrigo and van Dijken 2011, 2015), mainly due to increased light availability (Nicolaus et al. 2012). In contrast, increased freshwater input due to river runoff may result in decreased primary production, because of lower nutrient availability (Yun et al. 2016). Besides nutrient supply, other factors are also likely to affect Arctic ecosystem structure, such as oceanic $\mathrm{CO}_{2}$ uptake and increased temperatures (Tremblay et al. 2015).

In the central Arctic Ocean, the bulk of the total primary production is often generated by sea-ice algae rather than phytoplankton (Gosselin et al. 1997; Fernández-Méndez

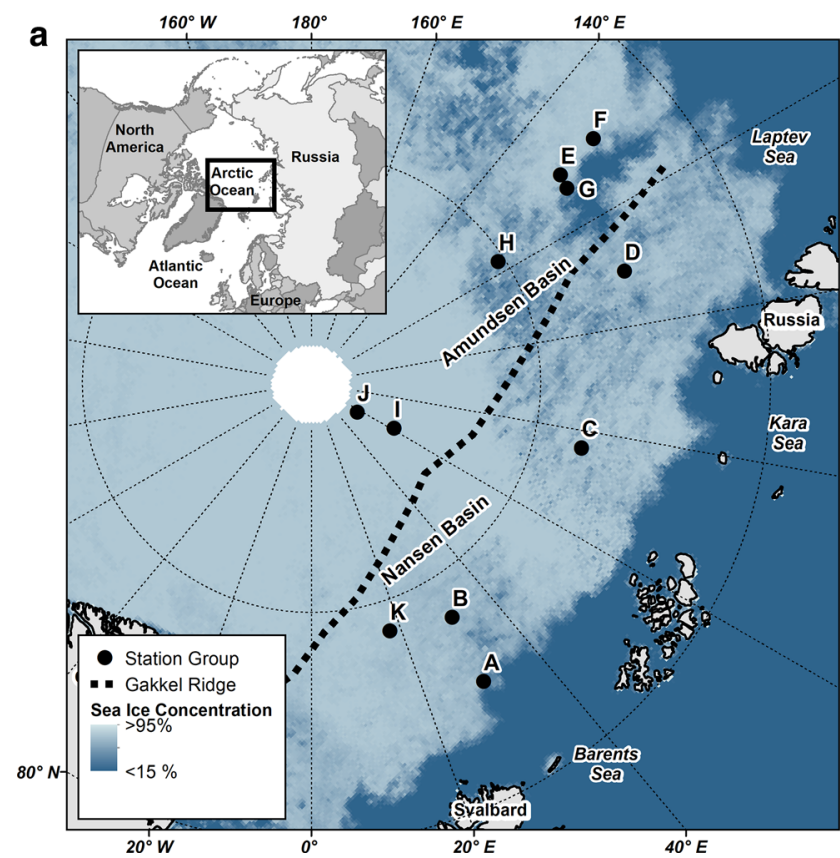

Fig. 1 Overview of the research area with sampling locations and major topographic features. Sea-ice concentration derived from SSMIS satellite data (www.meereisportal.de) is shown on 14th of et al. 2015). Reduced sea-ice algae production due to habitat/substrate loss can influence fundamental patterns of carbon flux in the food web. Recently, it was shown that abundant ecological key species, such as Calanus spp. and juvenile polar cod Boreogadus saida, significantly depend on carbon produced by ice algae (Budge et al. 2008; Søreide et al. 2010; Wang et al. 2015; Kohlbach et al. 2016, 2017). Kohlbach et al. (2016) demonstrated that the cumulative carbon demand by metazoan grazers far exceeded primary production rates by phytoplankton and sea-ice algae during summer. This suggests that intermediate trophic levels of the food web depend on heterotrophic carbon sources to a much greater extent than previously suggested (David et al. 2015; Kohlbach et al. 2016). While the transformation of Arctic sea-ice habitats continues, increased dependency on heterotrophic carbon transmitters may be a significant factor changing the trophic functioning of biological communities in the future Arctic Ocean.

In summer 2012, the lowest sea-ice extent since the beginning of satellite-based observations was recorded in the Arctic Ocean (Parkinson and Comiso 2013). In the Eurasian Basin of the Arctic Ocean, a vast area of rapidly degrading sea ice opened up in regions that are normally icecovered year-round (Fig. 1; Stroeve et al. 2012; Boetius et al. 2013). Interacting with the anomalous 2012 sea ice situation was a contrast between nutrient-rich Atlantic Water entering through the Fram Strait, nutrient-depleted Polar Water advected from the central Arctic Ocean, and shelf-influenced

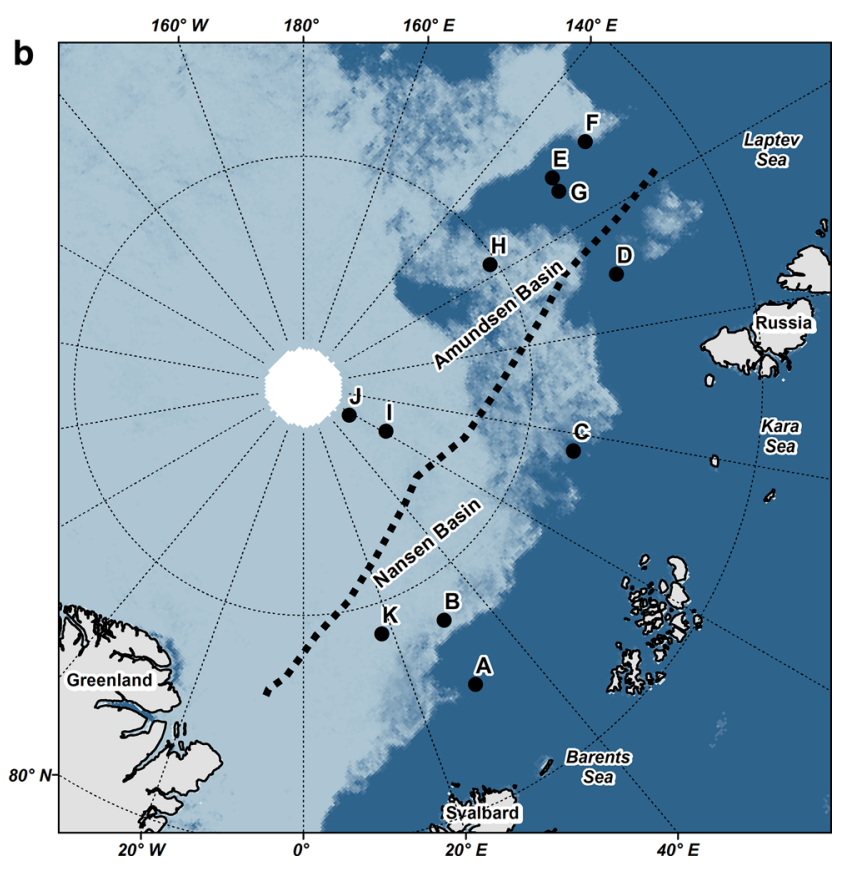

August (a) and 13th of September 2012 (b). Capital letters indicate sampling locations from Table 1 
water from the Laptev Sea (Lalande et al. 2014; David et al. 2015; Fernández-Méndez et al. 2015; Metfies et al. 2016). Sampling this unprecedented situation of extreme reduction of sea ice during Polarstern expedition PS80 gave the unique opportunity to sample both protist and metazoan communities simultaneously with hydrographical conditions, nutrient concentrations and sea-ice properties.

Changes in the taxonomic and trophic structure of these communities can have a strong impact on key ecosystem functions, such as primary and secondary production, carbon-, and nutrient cycling. The rapid environmental changes in the Arctic Ocean likely act differently on sea ice-associated communities compared to planktonic communities. In high-Arctic ecosystems, however, the response of biological communities to different drivers interacting with each other is poorly understood, especially in the under-ice habitat (Wassmann et al. 2011). In this study, we use a range of morphological, molecular, and statistical tools to analyse the structure of protist and metazoan communities both in the under-ice habitat and in the epipelagic habitat in the Eurasian Basin of the Arctic Ocean. We hypothesize that (1) the structure of both protist and metazoan communities responds to similar environmental drivers in each habitat; and (2) that changes in taxonomic composition in relation to environmental variability will be resembled in the trophic structure of these communities. To test these hypotheses, we:

(a) identified physical-chemical drivers structuring environmental regimes, such as sea-ice properties, hydrography and nutrient concentrations;

(b) analysed the relationship of the taxonomic composition of Arctic protist and metazoan communities with these environmental drivers;

(c) investigated if environmental drivers were associated with both the taxonomic and the trophic community structure.

\section{Material and methods}

\section{Research area}

The samples were collected from 7 August to 29 September 2012 during the RV Polarstern expedition PS80 (ARKXXVII/3, "IceArc") in the central Arctic Ocean (Fig. 1). The area sampled extended over the Eurasian Basin, ranging from $82^{\circ}$ to $89^{\circ} \mathrm{N}$, and from $30^{\circ}$ to $130^{\circ} \mathrm{E}$, and was entirely situated in deep-sea waters (depth range 3409-4384 m; Table 1). Samples and data were collected with various sampling gear at altogether 46 stations. For the purpose of this study, we grouped these stations into 11 locations identified by the letters $\mathrm{A}$ to $\mathrm{K}$, based on spatio-temporal proximity. Most sampling locations were associated with drifting sea-ice stations. The sampling around these locations, therefore, extended over a period of up to 3 days, and covered a latitudinal drift distance of up to $14.5 \mathrm{~nm}(28 \mathrm{~km})$. A complete account of all stations sampled for this study was provided in Table 1.

\section{Sampling of environmental parameters}

\section{Water column}

A conductivity temperature depth probe (CTD) with a carousel water sampler was used to collect environmental parameters from the water column. The CTD (Seabird SBE9+) was equipped with a fluorometer (Wetlabs FLRTD), a dissolved oxygen sensor (SBE 43) and a transmissiometer (Wetlabs C-Star). Details of the CTD sampling procedure were provided by Boetius et al. (2013). Data are available online in the PANGAEA database (Rabe et al. 2012). Nutrient samples were collected at multiple depths, and analysed in an air-conditioned lab container with a continuous flow auto analyser (Technicon TRAACS 800) following the procedure described by Boetius et al. (2013). Measurements were made simultaneously on four channels: $\mathrm{PO}_{4}, \mathrm{Si}, \mathrm{NO}_{2}+\mathrm{NO}_{3}$ together and $\mathrm{NO}_{2}$ separately. Nutrient values for the purpose of this study were taken from the depth of the chlorophyll $a$ maximum. The depth of the upper mixed layer (MLD) was calculated from the ship CTD profiles after Shaw et al. (2009). Integrated values for water temperature and salinity within the MLD were derived by averaging continuous CTD profile data between the surface and the MLD. A stratification index was estimated as the density gradient between the density of the mixed layer and the density of the water $5 \mathrm{~m}$ below the MLD.

\section{Under-ice habitat}

Under-ice metazoans and environmental parameters of the ice-water interface layer (0-2 m) were sampled with a Surface and Under-Ice Trawl (SUIT) (van Franeker et al. 2009). The SUIT consisted of a steel frame with a $2 \mathrm{~m} \times 2 \mathrm{~m}$ opening and two parallel $15 \mathrm{~m}$-long nets attached: (1) a $7 \mathrm{~mm}$ half-mesh commercial shrimp net, which covered $1.5 \mathrm{~m}$ of the opening width; and (2) a $0.3 \mathrm{~mm}$ mesh zooplankton net, which covered $0.5 \mathrm{~m}$ of the opening width. SUIT haul durations varied between 17 and $42 \mathrm{~min}$ ( mean = $29 \mathrm{~min}$ ) over an average distance of $1.5 \mathrm{~km}$. Water inflow speed and direction were calculated using a Nortek Aquadopp $®$ Acoustic Doppler Current Profiler (ADCP). The trawled area was calculated by multiplying the distance trawled in water, estimated from ADCP data, with the net width. The SUIT sampling technique and performance has been described in detail by David et al. (2015) and Flores et al. (2012). A sensor array was mounted on the SUIT frame, comprising among 
Table 1 Stations sampled during the expedition PS80. Nearby stations were grouped together as 'locations' represented by letters A to K

\begin{tabular}{|c|c|c|c|c|c|c|}
\hline Location & Station & Date & Latitude $\left({ }^{\circ} \mathrm{N}\right)$ & Longitude $\left({ }^{\circ} \mathrm{E}\right)$ & Depth (m) & Parameters \\
\hline \multirow[t]{2}{*}{ A } & PS80/215-1 & 08/07/2012 & 82.488 & 30.001 & 3618 & CTD \\
\hline & PS80/216-1 & 08/07/2012 & 82.483 & 30.027 & 3610 & ui-metazoans \\
\hline \multirow[t]{6}{*}{ B } & PS80/223-1 & 08/09/2012 & 84.070 & 30.434 & 4016 & ui-metazoans \\
\hline & PS80/224-1 & 08/09/2012 & 84.051 & 31.112 & 4014 & ice/ui-protists \\
\hline & PS80/226-1 & 08/09/2012 & 84.028 & 31.236 & 4013 & ep-metazoans \\
\hline & PS80/227-1 & 08/09/2012 & 84.026 & 31.225 & 4011 & CTD \\
\hline & PS80/230-1 & 08/11/2012 & 84.022 & 31.221 & 4011 & CTD/ep-protists \\
\hline & PS80/233-1 & $08 / 11 / 2012$ & 84.045 & 31.298 & 4011 & ui-metazoans \\
\hline \multirow[t]{4}{*}{$\mathrm{C}$} & PS80/237-1 & $08 / 14 / 2012$ & 83.987 & 78.103 & 3585 & ice \\
\hline & PS80/242-1 & 08/16/2012 & 83.902 & 76.067 & 3409 & CTD \\
\hline & PS80/243-1 & 08/16/2012 & 83.911 & 75.971 & 3418 & ep-metazoans \\
\hline & PS80/248-1 & 08/16/2012 & 83.934 & 75.500 & 3424 & ui-metazoans \\
\hline \multirow[t]{5}{*}{$\mathrm{D}$} & PS80/254-1 & 08/19/2012 & 82.696 & 109.119 & 3571 & CTD \\
\hline & PS80/255-1 & 08/20/2012 & 82.671 & 109.590 & 3569 & ice/ui-protists \\
\hline & PS80/256-1 & 08/20/2012 & 82.674 & 109.590 & 3571 & CTD/ep-protists \\
\hline & PS80/258-1 & $08 / 20 / 2012$ & 82.743 & 109.627 & 3575 & ui-metazoans \\
\hline & PS80/261-1 & $08 / 21 / 2012$ & 82.939 & 109.864 & 3599 & ep-metazoans \\
\hline \multirow[t]{5}{*}{ E } & PS80/276-1 & $08 / 25 / 2012$ & 83.076 & 129.125 & 4188 & ui-metazoans \\
\hline & PS80/277-1 & $08 / 25 / 2012$ & 82.883 & 130.130 & 4161 & ice \\
\hline & PS80/279-1 & $08 / 25 / 2012$ & 82.887 & 129.969 & 4166 & ep-metazoans \\
\hline & PS80/281-1 & $08 / 26 / 2012$ & 82.893 & 129.826 & 4186 & CTD \\
\hline & PS80/285-1 & $08 / 26 / 2012$ & 82.896 & 129.782 & 4174 & ui-metazoans \\
\hline \multirow[t]{6}{*}{$\mathrm{F}$} & PS80/321-1 & 09/04/2012 & 81.717 & 130.033 & 4011 & ui-metazoans \\
\hline & PS80/323-1 & 09/04/2012 & 81.926 & 131.129 & 4031 & ice/ep-protists \\
\hline & PS80/324-1 & 09/04/2012 & 81.925 & 131.120 & 4040 & CTD \\
\hline & PS80/328-1 & 09/05/2012 & 81.889 & 130.792 & 4036 & ep-metazoans \\
\hline & PS80/329-1 & 09/05/2012 & 81.876 & 130.878 & 4032 & CTD/ep-protists/ui-protists \\
\hline & PS80/331-1 & 09/05/2012 & 81.905 & 130.863 & 4011 & ui-metazoans \\
\hline \multirow[t]{2}{*}{ G } & PS80/333-1 & 09/06/2012 & 82.989 & 127.103 & 4036 & ui-metazoans \\
\hline & PS80/333-2 & 09/06/2012 & 83.003 & 127.177 & 4188 & CTD \\
\hline \multirow[t]{5}{*}{$\mathrm{H}$} & PS80/335-1 & 09/07/2012 & 85.102 & 122.245 & 4355 & ice/ep-protists/ui-protists \\
\hline & PS80/336-1 & 09/07/2012 & 85.100 & 122.255 & 4357 & CTD/ep-protists \\
\hline & PS80/337-1 & 09/07/2012 & 85.092 & 122.262 & 4356 & ep-metazoans \\
\hline & PS80/342-1 & 09/09/2012 & 85.158 & 123.349 & 4353 & CTD \\
\hline & PS80/345-1 & 09/09/2012 & 85.254 & 123.842 & 4354 & ui-metazoans \\
\hline \multirow[t]{4}{*}{ I } & PS80/349-1 & 09/18/2012 & 87.934 & 61.217 & 4380 & CTD/ep-protists/ui-protists \\
\hline & PS80/351-1 & $09 / 18 / 2012$ & 87.933 & 60.991 & 4384 & ep-metazoans \\
\hline & PS80/354-1 & $09 / 19 / 2012$ & 87.925 & 60.954 & 4384 & CTD \\
\hline & PS80/357-1 & $09 / 19 / 2012$ & 87.925 & 61.125 & 4381 & CTD/ep-protists \\
\hline \multirow[t]{4}{*}{$\mathrm{J}$} & PS80/360-1 & $09 / 22 / 2012$ & 88.828 & 58.864 & 4374 & ice/ep-protists/ui-protists \\
\hline & PS80/364-1 & $09 / 22 / 2012$ & 88.811 & 57.411 & 4375 & CTD \\
\hline & PS80/367-1 & $09 / 23 / 2012$ & 88.792 & 56.674 & 4375 & ep-metazoans \\
\hline & PS80/370-1 & $09 / 23 / 2012$ & 88.771 & 55.936 & 4377 & CTD/ep-protists \\
\hline \multirow[t]{5}{*}{ K } & PS80/384-1 & $09 / 28 / 2012$ & 84.375 & 17.454 & 3513 & ice/ep-protists/ui-protists \\
\hline & PS80/387-1 & $09 / 28 / 2012$ & 84.368 & 17.525 & 3897 & CTD \\
\hline & PS80/386-1 & $09 / 28 / 2012$ & 84.371 & 17.503 & 3774 & ep-metazoans \\
\hline & PS80/396-1 & $09 / 29 / 2012$ & 84.346 & 17.815 & 4015 & CTD/ep-protists \\
\hline & PS80/397-1 & 09/29/2012 & 84.172 & 17.922 & 4028 & ui-metazoans \\
\hline
\end{tabular}

$C T D$ water column parameters sampled with the ship's CTD (temperature, salinity, nutrients), ice sea-ice parameters, $u i$ under ice, $e p$ epipelagic 
other devices a CTD probe with built-in fluorometer and an altimeter used to derive ice thickness profiles and under-ice chlorophyll $a$ concentrations (David et al. 2015). Gridded daily sea-ice concentrations for the Arctic Ocean derived from SSMIS satellite data using the algorithm specified by Spreen et al. (2008), were downloaded from the sea-ice portal hosted at the University of Bremen (www.meereispor tal.de). For each sea-ice station, sea-ice concentration was averaged from nine adjacent grid cells, with the grid cell in which the station was situated as the centre. A detailed description of environmental sampling and parameter estimations was provided by David et al. (2015). An overview of the environmental parameters and their ranges was provided in Table 2.

\section{Chlorophyll a concentration}

Particulate organic matter (POM) from water samples was collected on Whatman GF/F glass fibre glass fibre filters $(0.7 \mu \mathrm{m})$, extracted in $90 \%$ acetone and analyzed with a Turner-Design fluorometer according to standard procedure (Edler 1979; Evans et al. 1987). Calibration of the fluorometer was carried out with standard solutions of Chlorophyll $a$ (Sigma, Germany). To estimate chlorophyll $a$ content of sea ice, ice cores were collected at each ice stations using a $9 \mathrm{~cm}$-diameter ice corer (Kovacs). Ice cores were cut in segments, which were each melted in $4{ }^{\circ} \mathrm{C}$ with $0.2 \mu \mathrm{m}$ filtered sea water in the dark. For details of sea-ice sampling see Boetius et al. (2013) and Lange et al. (2016). For pigment analysis of filtered ice core samples to each filter $50 \mu \mathrm{l}$ internal standard (canthaxanthi), $1.5 \mathrm{ml}$ acetone and small glass beads were added and the samples kept frozen at $-20^{\circ} \mathrm{C}$ for $15 \mathrm{~min}$. Cell were disrupted for $20 \mathrm{~s}$ with a Precellys ${ }^{\circledR}$ tissue homogenizer. The centrifugation of the extract was performed in a cooled centrifuge $\left(0^{\circ}\right)$ and the supernatant liquid was kept and filtered through a $17 \mathrm{~mm}$ HPLC $0.2 \mu \mathrm{m}$ PTFE filter (LABSOLUTE). Pigment measurement was carried out with a Waters HPLC-system equipped with an auto sampler (717 plus), a pump (600), a Photodiode array detector (2996), a fluorescence detector (2475) and the EMPOWER software. The analysis of the pigments was conducted by reverse-phase HPLC, with a VARIAN Microsorb-MV3 C8 column $(4.6 \times 100 \mathrm{~mm})$ and HPLC-grade solvent (Merck). For details see Kilias et al. (2013).

\section{Sampling of organisms from the under-ice and the pelagic habitats}

\section{Protists}

Sampling of epipelagic protists was carried out with a rosette sampler equipped with 24 Niskin bottles attached to the ship CTD. Samples were taken during the up-cast at the vertical maximum of chlorophyll $a$ fluorescence determined during the downcast. The sampling depth varied between 10 and $50 \mathrm{~m}$. Two-litre subsamples were transferred into PVC bottles. Under-ice protist samples were collected with a Kemmerer bottle (6.31) lowered through an ice hole directly below the ice. Protists were collected for molecular analyses by sequential filtration of one water sample through three different mesh sizes $(10 \mu \mathrm{m}, 3 \mu \mathrm{m}, 0.4 \mu \mathrm{m})$ at a vacuum pressure of -200 mbar using Isopore Membrane Filters (Millipore, USA). Filters were stored in Eppendorf tubes (Eppendorf, Germany) at $-80{ }^{\circ} \mathrm{C}$ until further processing in the laboratory.

In this study, we used a subset of an $18 \mathrm{~S}$ meta-barcodingdata set comprising a total of 56 samples collected in different ice-influenced habitats (Hardge et al. 2017a). DNA samples were processed as described in Hardge et al. (2017a). DNA extraction was carried out with the NucleoSpin® Plant II kit (Macherey-Nagel) following the manufacturer's protocol. The V4 region was amplified in triplicates using the
Table 2 Environmental parameters used in analyses

\begin{tabular}{|c|c|c|c|c|c|}
\hline Parameter & Code & Unit & Device & Min & Max \\
\hline Mean sea ice concentration & SIC & $\%$ & Satellite & 4 & 100 \\
\hline Modal ice thickness & SIT & $\mathrm{m}$ & SUIT CTD & 0 & 1.4 \\
\hline Mean temperature in the mixed layer & T.ML & ${ }^{\circ} \mathrm{C}$ & Ship CTD & -1.79 & -0.96 \\
\hline Mean salinity in the mixed layer & S.ML & PSU & Ship CTD & 30.06 & 33.36 \\
\hline Mean turbidity in the mixed layer & Tb.ML & $\%$ & Ship CTD & 93.22 & 95.56 \\
\hline Mixed layer depth & MLD & $\mathrm{m}$ & Ship CTD & 9 & 34 \\
\hline Stratification index & Strat & & Ship CTD & 0.02 & 1.19 \\
\hline $\mathrm{SiO}_{4}{ }^{2-}$ conc. at the chl $a$ maximum & $\mathrm{Si}$ & $\mu \mathrm{mol} 1^{-1}$ & Ship CTD & 1.17 & 4.80 \\
\hline $\mathrm{NO}_{3}{ }^{2-}+\mathrm{NO}_{2}{ }^{3-}$ conc. at the chl $a$ maximum & $\mathrm{NO}_{x}$ & $\mu \mathrm{mol} 1^{-1}$ & Ship CTD & 0.12 & 6.84 \\
\hline Mean chlorophyll $a$ conc. in sea ice & Chl.ice & $\mathrm{mg} \mathrm{m}^{-3}$ & Ice cores & 0.19 & 6.25 \\
\hline Mean chl $a$ conc. in the under-ice habitat & Chl.ui & $\mathrm{mg} \mathrm{m}^{-3}$ & SUIT CTD & 0.19 & 1.13 \\
\hline Mean chl $a$ conc. in the mixed layer & Chl.ML & $\mathrm{mg} \mathrm{m}^{-3}$ & Ship CTD & 0.06 & 0.30 \\
\hline
\end{tabular}

Chl $a$ chlorophyll $a$, Min minimum value, Max maximum value 
universal primer set TAReuk454FWD1 and TAReukREV3 (Stoeck et al. 2010). The DNA amplification was carried out in two rounds using a Mastercycler (Eppendorf, Germany). Resulting PCR products were purified with NucleoSpin ${ }^{\circledR}$ Gel \& PCR Clean up kit (Macherey-Nagel) according to the manufacturer's protocol. Pooled triplicates were sequenced on the MiSeq 18S meta-barcoding platform $(2 \times 300$ paired-end reads). The library preparation was done with the TruSeq RNA Library Preparation Kit v2 according to the manufacturer's protocol. We used QIIME version 1.8.0 (Caporaso et al. 2010) for sequence analysis. Operational taxonomic units (OTUs) were determined de novo at a minimum similarity threshold of $98 \%$. According to Bokulich et al. (2013), OTUs consisting of less than $0.005 \%$ of processed sequences were removed. Representative sequences of each OTU were aligned with the bioinformatics pipeline called PhyloAssigner (Vergin et al. 2013). The compiled reference database is available on request in ARB-format.

164 of the 210 protist taxa identified with sequence analysis were assigned to the trophic groups "autotrophs", "mixotrophs" and "heterotrophs" based on published knowledge on their trophic function (Online Resource ESM1). Based on the relative sequence abundance of combined OTUs with identical taxonomic labels, the proportional contribution of autotrophs, mixotrophs and heterotrophs was calculated for each sampling location.

\section{Metazoans}

Under-ice metazoans were sampled with the SUIT. After retrieval of the catch from the SUIT, the material was preserved in $4 \%$ formaldehyde/seawater solution for quantitative analysis. The samples were analysed for species composition and abundance at the Alfred Wegener Institute following the procedure described by David et al. (2015). In all macrofauna species, total body length was measured to the nearest $1 \mathrm{~mm}$ using a stereo microscope coupled to a digital image analysis system (Leica Model M 205C and image analysis software LAR 4.2). Copepods were classified by developmental stage and sex. Epipelagic metazoans were sampled with a Multinet (Hydrobios, Kiel). The Multinet had a mouth opening area of $0.25 \mathrm{~m}^{2}$ and was equipped with five nets $(150 \mu \mathrm{m})$, which were sequentially opened and closed to five sample discrete depth intervals (1500-1000-500-200-50-0 m). In the present study, only samples from the uppermost depth stratum $(0-50 \mathrm{~m})$ were considered. The samples were preserved in $4 \%$ formaldehyde/seawater solution buffered with borax. In the laboratory, the samples were subdivided with a plankton splitter (Hydrobios) usually to $1 / 8$ and at maximum to $1 / 64$. Abundant species ( $n>50$ in an aliquot) were sorted only from one subsample, while less abundant species were sorted from at least two subsamples. Areal abundances (ind. $\mathrm{m}^{-2}$ ) were calculated by dividing the total number of animals in each net by the water volume filtered, and multiplying the resulting volumetric density by the vertical depth range sampled.

We estimated the individual dry mass of freeze-dried SUIT samples of the five most abundant amphipod species. To account for the high variability in size distribution between sampling sites of the amphipod Themisto libellula, a size-dry weight relationships was established. This relationship was then used to estimate the dry mass of Themisto spp. at each station based on their total biovolume and mean size, respectively. Dry mass of Calanus copepods was estimated based on size- and stage composition data (Ehrlich 2015) and published individual dry mass values (Ashjian et al. 2003). Dry mass of all other taxa was calculated using published mean individual dry mass values (e.g. FalkPetersen et al. 1981; Ashjian et al. 2003). An account of individual dry weights, both measured and estimated from the literature, was provided in the Online Resource (ESM2).

Metazoan taxa were assigned to the trophic groups "herbivores", "omnivores" and "carnivores" based on published knowledge of their feeding ecology (Online Resource ESM2). Based on the relative dry mass of each taxon, the proportional contribution by mass of herbivores, omnivores and carnivores was calculated for each sampling location.

\section{Statistical analysis}

\section{Environmental data}

We used principal component analysis (PCA) to analyse spatial patterns in the environmental properties of sampling locations. In the PCA ordination, sampling locations having a similar structure in their environmental properties are grouped closer together than locations that show greater differences in environmental properties. The environmental gradients are shown relative to the ordination axes. Nearnormal distribution of data, as assumed by PCA, was confirmed by visual inspection of histograms. To achieve nearnormal distribution of the data, sea-ice concentration (SIC) was double-square transformed, mixed layer depth (MLD) and nitrate + nitrite concentration $\left(\mathrm{NO}_{x}\right)$ were square-root transformed, and the Stratification Index (Strat) was logtransformed (for all parameter codes see Table 2). To obtain an optimal representation of the structure of environmental data, we first performed a PCA with the full set of environmental parameters (Table 2), and then performed a stepwise backward selection, until the combination of parameters was found in which the cumulative proportion of variance of the first four components reached a maximum. From the PCA biplot, groups of locations with similar environmental properties ('regimes') were identified visually. Statistically significant differences in single environmental parameters between these regimes were assessed with an analysis of 
variance (ANOVA), followed by the Tukey Honest Significance test (Tukey HSD).

\section{Community analysis}

To analyse the relationship of the community structure with environmental parameters, we performed canonical correspondence analyses (CCA). The CCA ordination groups sampling locations that have a similar taxonomic structure closer together than locations that show greater differences in taxonomic structure. In addition, it projects this ordination in relation to environmental gradients for assessing the association of taxonomic structure with environmental parameters. CCAs were conducted for each of the four communities: under-ice protists, epipelagic protists, under-ice metazoans, and epipelagic metazoans. Square-root transformation and Wisconsin standardization were applied to under-ice and epipelagic metazoan data. In each CCA, combinations of up to four environmental parameters were sequentially selected based on the maximum contribution of eigenvalues to the mean-squared contingency coefficient (cumulative proportion). In the final CCA of each community, the cumulative proportion reached at least $50 \%$, and the joint effect of constraints was significant. The significance of the joint effect of constraints was tested with an ANOVAlike permutation test for CCA using 1000 permutations (in R termed 'anova.cca', Oksanen et al. 2013).

\section{Trophic structure}

We used Student's $t$ test to test for significant differences in the proportional contribution of single trophic groups between NOx-poor and NOx-rich regimes. To analyse the relationship of trophic groups with environmental parameters in more detail, we used generalized linear models (GLM, McCullagh and Nelder 1989). GLMs are used to fit relationships of single response variables (e.g. 'percentage of herbivores') with combinations of one or more explanatory variables (here: environmental parameters), thereby allowing to choose appropriate assumptions about the error distribution of the model. In this study, we modelled the proportion of each trophic group in each community (response variable) in relation to up to two environmental parameters (explanatory variables). Because the response variables were proportional data, we assumed a binomial error distribution with a flexible dispersion parameter (in R termed 'quasibinomial'). The same transformations as in the PCA were applied to SIC, MLD, Strat and $\mathrm{NO}_{x}$ to achieve near-normal distribution of the data. To find the most parsimonious model, we sequentially added up to two environmental parameters to each model and retained those parameters which had significant model terms and the lowest residual deviance.
For all analyses, we used Rs software version 3.5.2 (R Core Team 2017).

\section{Results}

\section{Environmental properties}

The research area was characterised by mixed layer depths (MLD) between 9 and $34 \mathrm{~m}$, and chlorophyll $a$ concentrations in the mixed layer (Chl.ML) ranged from 0.06 to $0.30 \mathrm{mg} \mathrm{m}^{-3}$ (Table 2). Location A was situated at the ice edge and was the only location where water temperatures in the mixed layer (T.ML) were $>-1{ }^{\circ} \mathrm{C}$ (Fig. 2a). All other stations were situated within the pack-ice during the early (locations B-D; Fig. 1a), or during the late phase of the sampling period (locations I-K; Fig. 1b). Locations A and E-H were positioned close to large open water areas (Fig. 1b). They shared low values of salinity in the mixed layer (S.ML) and relatively low values of sea-ice concentration (SIC) and thickness (SIT), indicating an advanced state of sea-ice melt (Fig. 2b, g, h). Locations D-J were characterised by lower nitrate + nitrite concentrations at the depth of the chlorophyll $a$ maximum $\left(\mathrm{NO}_{x} ;<2.5 \mu \mathrm{mol} 1^{-1}\right)$ than the other locations. In this group, locations $\mathrm{E}-\mathrm{H}$ showed elevated silicate concentrations at the depth of the chlorophyll $a$ maximum (Si; Fig. 2e). At locations A-C and $\mathrm{K}, \mathrm{NO}_{x}$ values exceeded $3.5 \mu \mathrm{mol} \mathrm{l}^{-1}$ (Fig. 2f).

A principle component analysis (PCA) including the environmental parameters $\mathrm{NO}_{x}$, S.ML, SIC, Si and T.ML could explain $99.85 \%$ of the first four principle components. The biplot of the first two components (explaining altogether $92.64 \%$ of the variance) showed that the most pronounced environmental gradient in the research area followed the variability of S.ML and Si along component axis 1 (Fig. 3). This 'shelf-ocean' gradient reflected the transition from locations E-H off the Laptev Sea, characterised by the fresh, silicate-rich waters and decaying sea ice ('shelfinfluenced regime') to the silicate-poor, more oceanic locations A-D and I-K. (Figs. 2b, e, 3). Crossing this shelfocean gradient, an ' $\mathrm{NO}_{x}$ ' gradient reflected the transition from $\mathrm{NO}_{x}$-poor waters at the shelf-influenced regime $(\mathrm{E}-\mathrm{H})$ and a 'Polar regime' with low $\mathrm{Si}$ values $(\mathrm{D}, \mathrm{I}, \mathrm{J})$ to $\mathrm{NO}_{x}$-rich waters entering from the Fram Straight at locations A-C and K ('Atlantic regime'; Figs. 2f, 3). Mean values of Si and $\mathrm{NO}_{x}$ were significantly different between the regimes separated by these two interacting gradients (Si: ANOVA, $F_{2}=23.18, p<0.001$, Tukey HSD: Shelf-influenced versus Atlantic regime $p=0.001 /$ Shelf-influenced versus Polar regime $p<0.001 ; \mathrm{NO}_{x}$ : ANOVA, $F_{2}=14.01, p=0.002$, Tukey HSD: Polar versus Atlantic regime $p=0.009 /$ Shelf/ influenced versus Atlantic regime $p=0.003$ ). 
Fig. 2 Environmental properties at the sampling locations. Environmental parameters have the same codes as shown in Table 2: T.ML water temperature in the mixed layer (a), S.ML salinity in the mixed layer (b), $M L D$ mixed layer depth (c), Strat stratification index (d),

Si Silicate concentration at the depth of the chlorophyll $a$ maximum (e), $N O_{x}$ Nitrate + Nitrite concentration at the depth of the chlorophyll a maximum (f), SIC sea ice concentration (g), SIT ice thickness (h). Capital letters indicate sampling locations from Table 1 . The bars are coloured according to environmental regimes identified with the PCA (Fig. 3): brown shelf-influenced regime (Locations E-H); orange Atlantic regime (Locations A-C, K), turquoise $=$ Polar regime (Locations D, I, J).

(Color figure online)
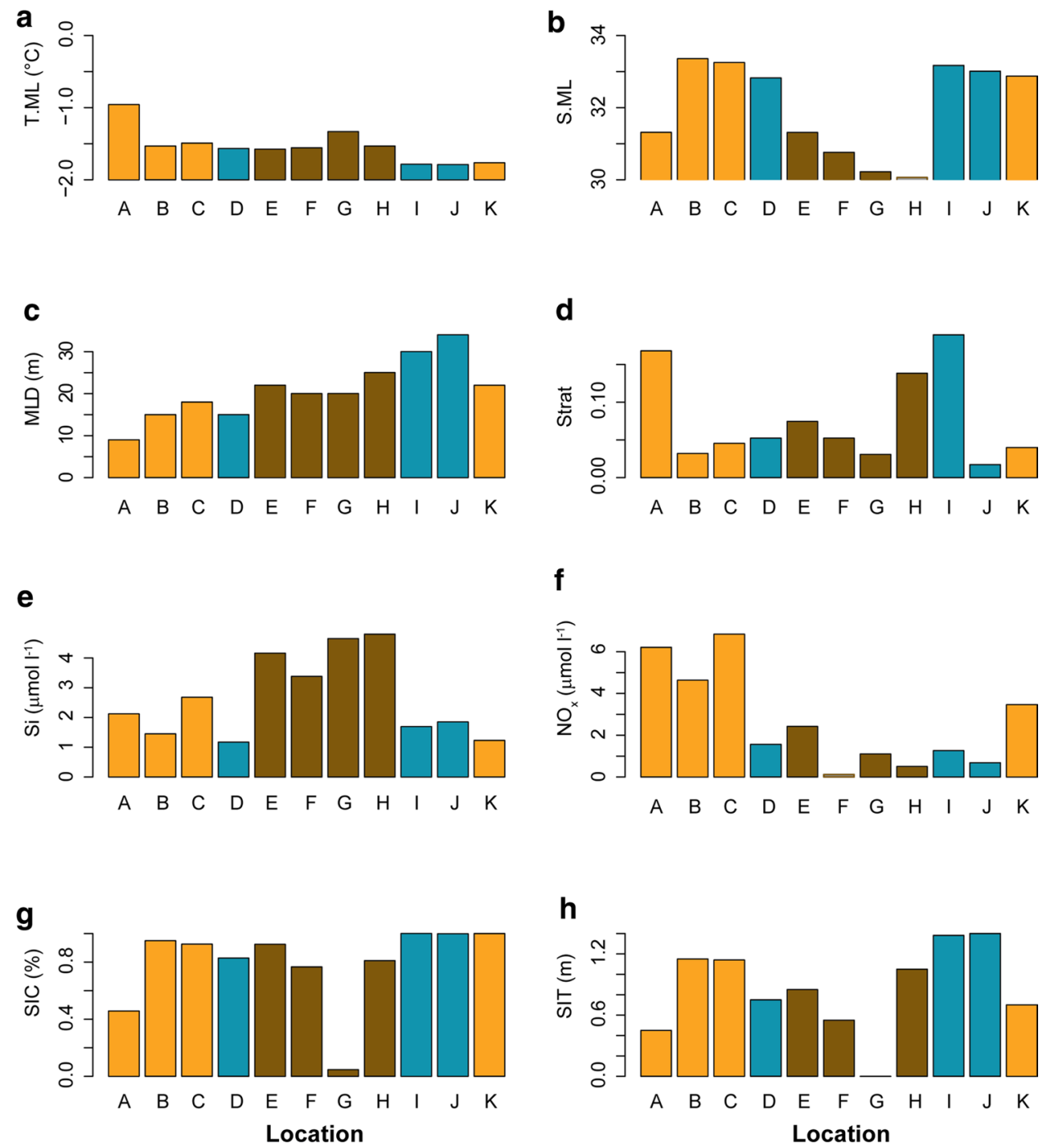

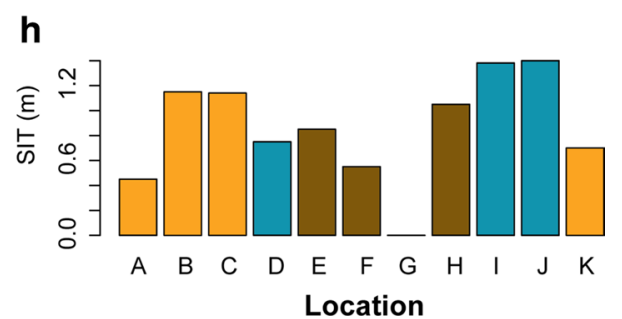

\section{Community structure}

\section{General community composition}

From the 11 locations considered in this study, we sampled 7 locations for under-ice and epipelagic protists, 9 locations for under-ice metazoans, and 9 locations for epipelagic metazoans (Table 1). In each community, the sampling included locations from all three environmental regimes. In the protist community from under-ice water, OTUs from dinoflagellates ( $\sim 40 \%$ of total sequences) dominated, with the highest sequence abundances in the Gymnodiniaceae (Gymnodinium spp., Karlodinium spp. and Gyrodinim spp.). In the epipelagic layer, the share of OTUs from non-dinoflagellate heterotrophic protists was often higher than the share of dinoflagellate OTUs, with the highest sequence abuncances in Ciliophora (Oligotrichea). The under-ice metazoan community comprised both ice-associated and pelagic species. It was numerically dominated by the ice-associated amphipod
Apherusa glacialis, and the pelagic copepods Calanus glacialis and $C$. hyperboreus. The epipelagic metazoan community was dominated by copepods in numbers and biomass. By far the most abundant species were $C$. hyperboreus and Calanus spp. (predominantly $C$. finmarchicus). Detailed analyses of the taxonomic composition of protist and metazoan communities were provided in David et al. (2015), Ehrlich (2015) and Hardge et al. (2017a).

\section{Community structure in relation to environmental parameters}

In all four communities, the ordination followed gradients of sea-ice influence (SIC, SIT), stratification (MLD, Strat) and shelf influence (S.ML, Si; Table 3). With two exceptions (under-ice metazoans: location A in Fig. 4c; epipelagic metazoans: location $\mathrm{C}$ in Fig. 4d), locations with high sea-ice influence (B-C, I-K) were separated along the SIC/ SIT gradient from those with lower sea-ice influence (D-H; 


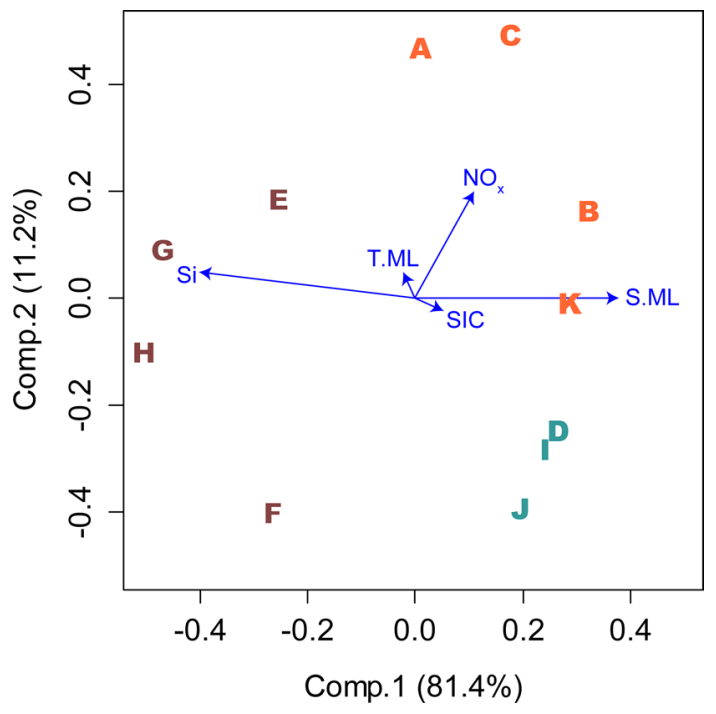

Fig. 3 Biplot of a principle component analysis (PCA) of environmental properties in the research area. Capital letters represent sampling locations from Table 1. Letters were colour-coded according to visually identified oceanographic regimes: brown $=$ shelf-influenced regime $($ Locations E-H); orange $=$ Atlantic regime (Locations A-C, $\mathrm{K}$ ), turquoise $=$ Polar regime (Locations $\mathrm{D}, \mathrm{I}, \mathrm{J}$ ). Blue arrows point into the direction of increasing values of environmental parameters in the ordination. Percentage values in axis annotations indicate proportion of explained variance of the PCA. Environmental parameters (Table 2): $N O_{x}$ Nitrate + Nitrite concentration at the depth of the chlorophyll $a$ maximum, $S . M L$ salinity in the mixed layer, $S i$ Silicate concentration at the depth of the chlorophyll a maximum, SIC sea ice concentration, T.ML temperature in the mixed layer. (Color figure online)

Figs. 2, 4). $\mathrm{NO}_{x}$ was only important in protist communities (Table 3, Fig. 4a, b).

\section{Trophic structure}

Whereas the taxonomic structure of all four communities predominantly reflected the variability of sea-ice influence, stratification and shelf influence (Table 3, Fig. 4), the trophic structure differed predominantly between locations in the
$\mathrm{NO}_{x}$-rich Atlantic regime and locations in the $\mathrm{NO}_{x}$-poor Polar and shelf-influenced regimes.

The protist community of the under-ice water was dominated by OTUs of mixotrophic taxa, reflecting the high share of OTUs from dinoflagellates (Hardge et al. 2017a). Locations in $\mathrm{NO}_{x}$-poor waters of the polar and shelf-influenced regimes (D, F and $\mathrm{H}-\mathrm{J}$ ) had a significantly higher share of heterotrophy-associated OTUs than locations of the Atlantic regime (B, K; $t$ test: $t_{2.24}=6.32, p<0.05$; Fig. 5a). Within the $\mathrm{NO}_{x}$-poor regimes, locations associated with thicker ice $(\mathrm{H}-\mathrm{J})$ had proportionally higher shares of OTUs indicative of autotrophic taxa compared to locations with thinner, decaying sea ice (D, F; Figs. 2h, 5a).

In the epipelagic protist community, OTUs of heterotrophs were generally more abundant compared to the protist community sampled in the under-ice layer, reflecting the high share of protozoan sequences in this community (Hardge et al. 2017a). Similar to the under-ice protist community, the proportion of heterotrophic OTUs was higher at the $\mathrm{NO}_{x}$-poor locations in the Shelf-influenced and Polar regimes $(\mathrm{D}, \mathrm{F}, \mathrm{H}-\mathrm{J})$ than at locations in the Atlantic regime $(\mathrm{B}, \mathrm{K})$, but this pattern was not statistically significant $(t$ test: $p>0.05)$. Rather, the share of OTUs from mixotrophs was significantly lower, and the share of OTUs from autotrophs was significantly higher at $\mathrm{NO}_{x}$-poor locations compared to locations in the Atlantic regime ( $t$ test; mixotrophs: $t_{4.42}=-4.58, p<0.01$; autotrophs: $t_{4.63}=4.98, p<0.01$; Fig. 5b).

The under-ice metazoan community was characterized by a high variability in the biomass share of herbivores, ranging from $<30$ to $>90 \%$ (Fig. $5 \mathrm{c}$ ). The biomass share of herbivores decreased along the more open and fresher surface water at stations D-G with relatively thin ice (Figs. 1, $2 \mathrm{~h}, 5 \mathrm{c})$. At $\mathrm{NO}_{x}$-poor locations in the shelf-influenced and Polar regimes $(\mathrm{D}-\mathrm{H})$, the proportional biomass of herbivores was significantly lower, and proportional biomasses of carnivores was significantly higher compared to locations in the Atlantic regime $(\mathrm{A}-\mathrm{C}, \mathrm{K})\left(t\right.$ test: herbivores: $t_{9.75}=2.91$, $p<0.05$; carnivores: $\left.t_{6.93}=-2.56, p<0.05\right)$.
Table 3 Significant (CCA-ANOVA; $p<0.05)$ combinations of environmental parameters explaining $>50 \%$ of the variability in the CCA ordination of protist and metazoan communities at the ice-water interface and in the epipelagic habitat. In each CCA, the selected significant environmental parameters were indicated by the letter " $\mathrm{x}$ "

\begin{tabular}{llllllll}
\hline Community & Prop & MLD & Strat & $\mathrm{NO}_{x}$ & $\mathrm{~S} . \mathrm{ML}$ & $\mathrm{Si}$ & $\mathrm{SIC}$ \\
\hline uiw-protists & 0.81 & $\mathrm{x}$ & $\mathrm{x}$ & & $\mathrm{x}$ & $\mathrm{x}$ \\
uiw-metazoans & 0.55 & $\mathrm{x}$ & & $\mathrm{x}$ & $\mathrm{x}$ & $\mathrm{x}$ \\
ep-protists & 0.75 & $\mathrm{x}$ & $\mathrm{x}$ & $\mathrm{x}$ & $\mathrm{x}$ & $\mathrm{x}$ \\
ep-metazoans & 0.58 & & $\mathrm{x}$ & & $\mathrm{x}$ & $\mathrm{x}$ \\
\hline
\end{tabular}

Habitats: uiw under-ice water, ep pipelagic; Env. parameters: $M L D$ mixed layer depth, $\mathrm{NO}_{x}=$ Nitrate + Nitrite concentration at the depth of the chlorophyll $a$ maximum, S.ML salinity in the mixed layer, $S i$ silicate concentration at the depth of the chlorophyll $a$ maximum, SIC sea ice concentration, Strat stratification index, SIT ice thickness. Statistics: prop. $=$ proportional contribution of eigenvalues to constraints 

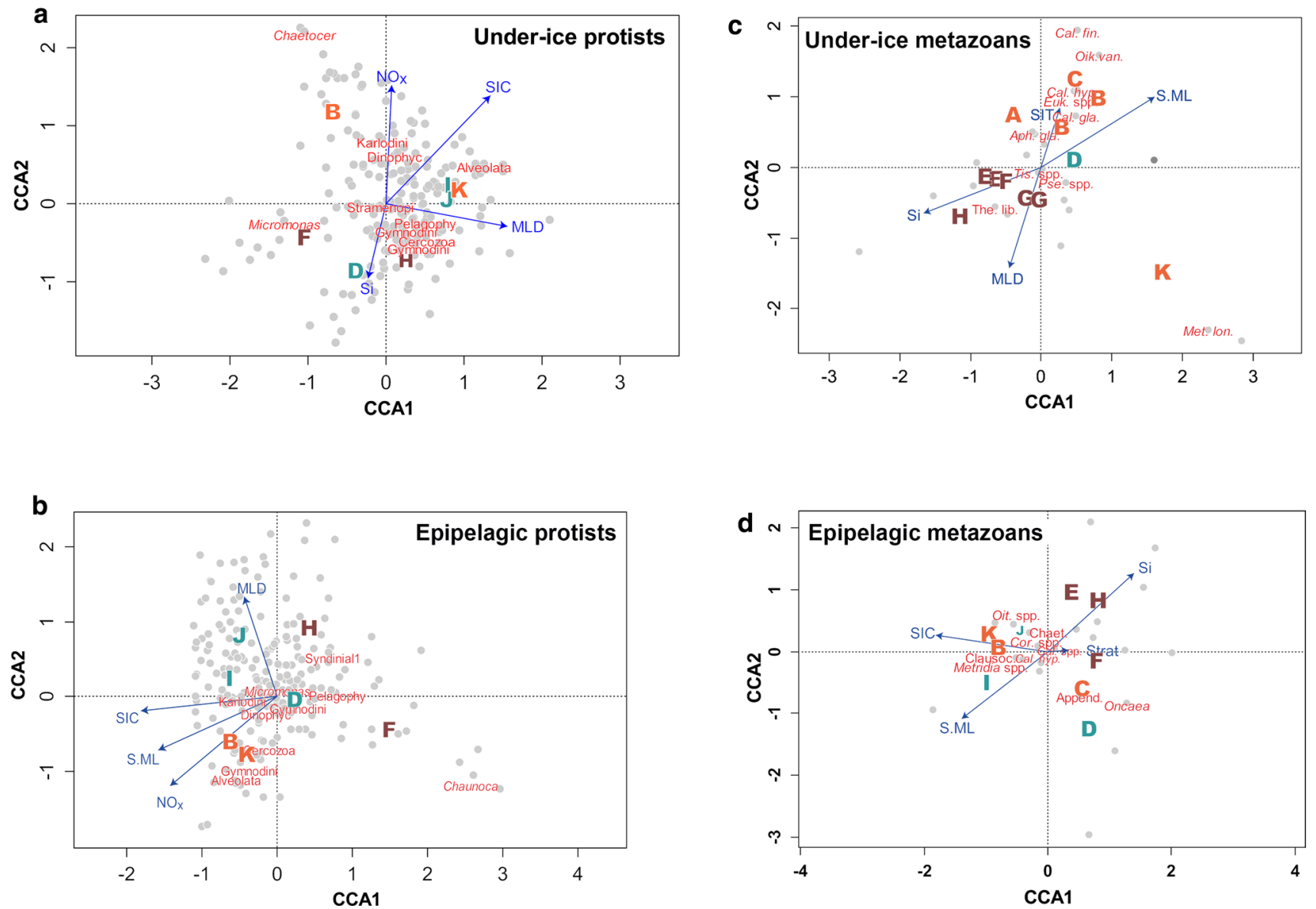

Fig. 4 Biplots from a canonical correspondence analysis (CCA) of under-ice protist (a), epipelagic protist (b), under-ice metazoan (c) and epipelagic metazoan (d) communities in relation to environmental gradients. Capital letters in biplots indicate sampling locations (Table 1). Letters were colour-coded according to oceanographic regimes (Fig. 3): brown = shelf-influenced regime (Locations E-H); orange $=$ Atlantic regime $($ Locations $\mathrm{A}-\mathrm{C}, \mathrm{K})$, turquoise $=$ Polar regime (Locations D, I, J). Blue arrows point into the direction of increasing values of environmental parameters in the ordination. Grey

In the epipelagic metazoan community, the variability of the biomass share of herbivores versus carnivores showed a similar pattern compared to the under-ice protist and underice metazoan communities (Fig. 5 a, b, d). Accordingly, at $\mathrm{NO}_{x}$-poor locations in the shelf-influenced and Polar regimes (D-F, H-J), the proportional biomass of herbivores was significantly lower, and the proportional biomass of omnivores and carnivores was significantly higher compared to locations in the Atlantic regime $(\mathrm{B}, \mathrm{C}, \mathrm{K})(t$ test; herbivores: $t_{3.06}=4.10, p<0.05$; omnivores: $t_{3.19}=-3.45, p<0.05$; carnivores: $\left.t_{3.06}=-3.85, p<0.05\right)$.

To more accurately investigate the relationship of trophic structure with the variability of environmental parameters interacting with each other, we used GLMs to analyse the combined effect of up to two environmental parameters on the relative share of each trophic group from

dots indicate the position of individual protist OTUs and metazoan taxa in the ordination. The corresponding taxonomic information is provided in the Online Resource (ESM1, ESM2). Environmental parameters (Table 2): $M L D$ mixed layer depth, $N O_{x}$ Nitrate + Nitrite concentration at the depth of the chlorophyll $a$ maximum, S.ML salinity in the mixed layer, $S i$ Silicate concentration at the depth of the chlorophyll $a$ maximum, SIC sea ice concentration, Strat = stratification index, SIT = ice thickness. (Color figure online)

each community in each habitat. In 10 of the 12 models, the selection procedure resulted in 'best' models with significant effects $(p<0.05)$ (Table 4$)$. In under-ice communities, the proportional contribution of each trophic group was associated with different environmental parameters. For the under-ice protist community, the selected GLMs indicated that temperature and turbidity of the mixed layer had a positive effect on the share of autotrophs, while heterotrophs were negatively related to $\mathrm{NO}_{x}$ values and positively related to chlorophyll $a$ concentrations in sea ice. The share of mixotrophs was negatively related to ice thickness (Table 4). In under-ice metazoan models, S.ML was the only environmental parameter related to the two trophic groups to which a GLM could be fitted. S.ML had a positive effect on the share of herbivores, and a negative effect on the share of carnivores (Table 4). Because this 

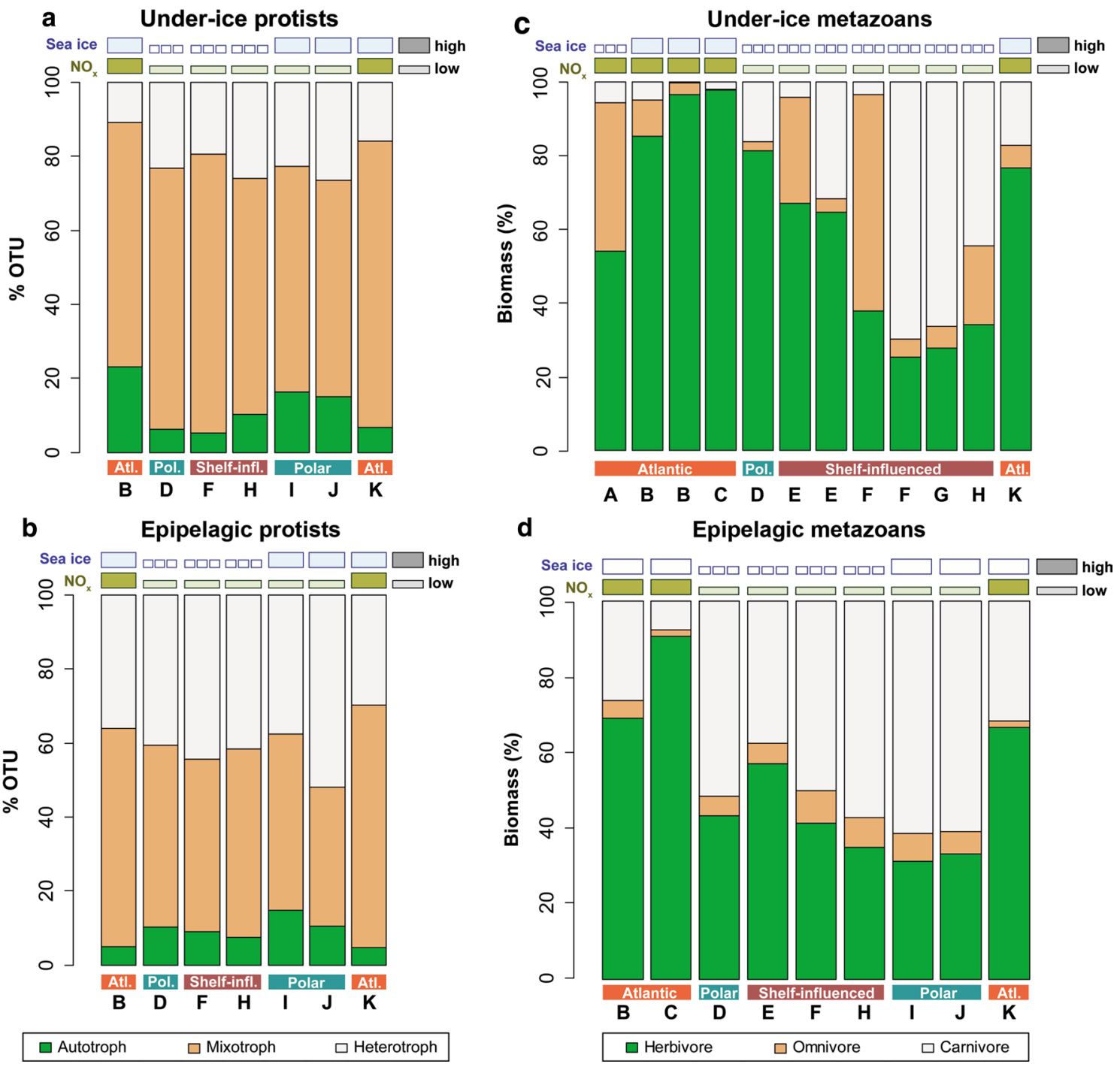

Fig. 5 Trophic structure of under-ice protist (a), epipelagic protist (b), under-ice metazoan (c) and epipelagic metazoan (d) communities. The heights of the coloured sections in the bars indicate the proportional abundances of operational taxonomic units (OTU) in protist communities and biomass shares in metazoan communities. Capital letters indicate sampling locations from Table 1. Duplicate letters indicate repeated sampling at the same location (Table 1). Symbols

above the bars indicate either 'high' or 'low' conditions of sea ice and NOx, respectively, based on the data shown in Fig. 2. The coloured horizontal blocks below the bars indicate the 3 hydrographical regimes of the research area: Atlantic regime (orange), shelf-influenced regime (brown), and Polar regime (turquoise). (Color figure online)

community was not sampled at locations I and J, however, the variability of S.ML largely coincided with the variability of $\mathrm{NO}_{x}$ in this dataset.

In the epipelagic layer, $\mathrm{NO}_{x}$ had a significant effect in all five GLMs fitted (Table 4). The two trophic groups of protist communities to which a GLM could be fitted were both associated with the chlorophyll $a$ concentration in the mixed layer (Chl.ML) and $\mathrm{NO}_{x}$, with a positive effect in the model of mixotrophs, and a negative effect of these parameters in the model of heterotrophs (Table 4). In epipelagic metazoan models, $\mathrm{NO}_{x}$ was the only environmental parameter significantly related to all three trophic groups, with a positive

effect in the model of herbivores and negative effects in the models of omnivores and carnivores (Table 4).

\section{Discussion}

\section{Structure of the environment}

In summer 2012, the Eurasian Basin was characterised by extremely low sea-ice coverage, super-imposed on environmental gradients determined by the large-scale hydrography of the Arctic Ocean. Sea-ice-conditions changed from a 
Table 4 Summary of 'best' Generalized Linear Models (GLM) of the relationship between the proportional contribution of trophic groups and environmental parameters in protist and metazoan communities in the under-ice layer and the epipelagic layer

\begin{tabular}{|c|c|c|c|c|c|c|c|c|c|}
\hline Community & $\begin{array}{l}\text { Trophic } \\
\text { group }\end{array}$ & $R D$ & T.ML & S.ML & Tb.ML & Chl.ML & $\mathrm{NO}_{\mathrm{x}}$ & SIT & Chl.ice \\
\hline uiw-protists & Autotrophs & 0.04 & + & & + & & & & \\
\hline uiw-protists & Mixotrophs & 0.02 & & & & & & - & \\
\hline uiw-protists & Heterotrophs & 0.02 & & & & & - & & + \\
\hline uiw-metazoans & Herbivores & 0.50 & & + & & & & & \\
\hline uiw-metazoans & Omnivores & - & \multicolumn{7}{|c|}{ no model fitted } \\
\hline uiw-metazoans & Carnivores & 2.16 & & - & & & & & \\
\hline ep-protists & Autotrophs & - & \multicolumn{7}{|c|}{ no model fitted } \\
\hline ep-vprotists & Mixotrophs & 0.02 & & & & + & + & & \\
\hline ep-protists & Heterotrophs & 0.01 & & & & - & - & & \\
\hline ep-metazoans & Herbivores & 0.29 & & & & & + & & \\
\hline ep-metazoans & Omnivores & 0.03 & & & & & - & & \\
\hline ep-metazoans & Carnivores & 0.30 & & & & & - & & \\
\hline
\end{tabular}

The directional effect of each parameter on the response variable is indicated by "+" signs (dark shading) and "-" signs (light shading)

Habitats: $e p$ epipelagic, uiw under-ice water; Environmental parameters: Chl.ice chlorophyll $a$ concentration in sea ice, Chl.ML chlorophyll $a$ concentration in the mixed layer, $N O_{x}$ nitrate + nitrite concentration at the depth of the chlorophyll $a$ maximum, S.ML salinity in the mixed layer, SIT ice thickness, $T b . M L$ turbidity in the mixed layer, T.ML temperature in the mixed layer; statistics: $R D$ residual deviance of GLM

Significance of model terms: ${ }^{*} p<0.05, * * 0.05<p<0.001 ; * * * p<0.001$

nearly closed sea-ice cover at the beginning of our sampling in the Nansen Basin (Fig. 1a), through an opening area of rapid sea-ice melt in the Laptev Sea sector south of $86^{\circ} \mathrm{N}$, and back into freezing conditions at higher latitudes and towards the end of the survey in late September (Fig. 1b). Sea-ice concentration (SIC) was a significant, but not very pronounced contributor to our PCA (Fig. 3). However, the vast ice-free zone in the Laptev Sea sector may have been under-represented by our satellite-derived sea-ice concentration values from the relatively small areas around our icecovered sampling stations (Fig. 1b). In the epipelagic layer, the most pronounced environmental gradient was created by the silicate concentration in the chlorophyll $a$ maximum (Si). The high-silicate concentrations at locations $\mathrm{E}-\mathrm{H}$ in the shelf-influenced regime reflected the influence of Laptev Sea water carrying high amounts of silicate originating from the Lena delta inflow, as compared to the low $\mathrm{Si}$ values at all other locations (Fig. 2; Bauch et al. 2014; Bluhm et al. 2015). The salinity in the mixed layer (S.ML) varied largely in the opposite direction of the silicate gradient (Figs. 2, 3). Crossing this silicate/salinity gradient, Nitrate + Nitrite concentrations in the chlorophyll $a$ maximum $\left(\mathrm{NO}_{x}\right)$ changed from high values in the Atlantic regime (locations A-C, K) to low values in the shelf-influenced and Polar regime (locations D-J). This large-scale $\mathrm{NO}_{x}$-gradient was consistent with the known pattern of $\mathrm{NO}_{x}$ distribution in the Arctic Ocean during summer (Codispoti et al. 2013; Bluhm et al. 2015): In the Eurasian Basin, nitrate is predominantly advected by the Atlantic water inflow through the Fram Strait and across the Barents Sea, and transported along the Eurasian shelf break, where our sampling locations A-C and $\mathrm{K}$ were situated. After reaching the Laptev Sea sector, surface waters are depleted of $\mathrm{NO}_{x}$ and recirculated across the Eurasian Basin towards the Fram Strait, passing the positions of our $\mathrm{NO}_{x}$-poor sampling locations D-J (Kattner et al. 1999; Rudels et al. 2013; Bluhm et al. 2015).

\section{Taxonomic community structure}

Gradients of sea-ice influence (SIC, SIT), stratification of the water column (MLD, Strat) and shelf influence (S.ML, $\mathrm{Si})$ were common drivers of the community structure in all four communities (Table 3). The effects of these drivers on community composition cannot be entirely disentangled from each other, because the directions of their gradients often overlapped in the CCA ordination (Fig. 4). However, the general pattern in the four CCA ordinations showed that locations associated with low sea-ice influence were separated from stations with high sea-ice influence along gradients of sea-ice properties (SIC, SIT; Fig. 4). Sea ice 
influences protist communities in the water column primarily by limiting light intrusion, affecting photo-autotrophic growth (Sakshaug 2004). Other important factors influencing protist community composition are limitation of nutrient supply from deeper water layers due to enhanced stratification under melting sea ice (Fujiwara et al. 2014), and exchange between the water column and in-ice communities through physical processes and active migration (Hardge et al. 2017a). The observed relationship between protist community structure and sea-ice properties contrasts an extensive analysis by Ardyna et al. (2011) in the Canadian Arctic, which found that sea iceconditions played only a minor role. The work of Ardyna et al. (2011) was conducted on the Pacific-influenced shelf of the Canadian Archipelago, whereas our study was conducted in the deep Eurasian Basin. Apart from these biogeographical differences, it is possible that the range of mean sea-ice concentrations (2-23\%) observed by Ardyna et al. (2011) in late summer was too limited to significantly affect protist communities through shading, stratification, or organism exchange. In agreement with Ardyna et al. (2011), the structure of protist communities in our study was also significantly related to $\mathrm{NO}_{x}$ gradients. In metazoan communities, however, a significant influence of $\mathrm{NO}_{x}$ was not observed in our dataset (Table 3).

In the under-ice metazoan community, a strong response to sea-ice influence was expected due to the high proportional abundance of sea ice-associated (sympagic) amphipods, e.g. Apherusa glacialis and Onisimus glacialis (Hop et al. 2000; Poltermann et al. 2000; Gradinger and Bluhm 2004; Bluhm et al. 2010). David et al. (2015) observed that the under-ice metazoan community structure differed between a densely ice-covered 'Nansen Basin regime' (corresponding to the Atlantic regime in the present study), and a more open 'Amundsen Basin regime' (the Shelf-influenced regime in the present study) in summer 2012. Our observation that sea-ice concentration was an important factor structuring the epipelagic metazoan community (Table 3 ) is in agreement with a multi-annual study in the Western Arctic Ocean finding that the contribution of sea-ice concentration to the variability in zooplankton community structure ranked highest together with bathymetry among numerous investigated environmental parameters (Hunt et al. 2014). In the epipelagic metazoan community ordination, crossing gradients of sea-ice properties (SIC) and shelf influence (S.ML, Si) indicated that, in combination with sea-ice influence, the epipelagic metazoan community structure responded to shelf influence (Fig. 4d). Most high-Arctic zooplankton studies focused on horizontal and vertical differences in community structure in relation to large, physically defined water masses and bathymetrically defined habitats (e.g., Mumm et al.
1998; Kosobokova and Hirche 2000; Wassmann et al. 2015). The shelf-influence gradient (S.ML/Si) of our CCA resembled such a hydrographical pattern (Fig. 4d).

In the Eurasian Basin, plankton communities are strongly influenced by Atlantic species advected through the Fram Strait and the Barents Sea (Wassmann et al. 2015). While in our research area, the advection of Atlantic species is tied to the distribution of Atlantic water flowing eastward along the continental slope at depths below $100 \mathrm{~m}$, surface waters of Polar origin are associated with the westward Transpolar Drift transporting sea ice from Siberia towards the Fram Strait. Advection of Polar species with surface waters thus probably contributed partly to the sea ice-associated gradient in protist and metazoan community structure. The sea ice itself may have advected species from the Siberian shelf, as has been found for seaice protists by Hardge et al. (2017a), and for polar cod Boreogadus saida by David et al. (2016). Besides the physical properties of sea ice, the presence of ice algae may have attracted certain zooplankton and sympagic species, and contributed to a sea-ice-driven trend in underice and epipelagic metazoan community composition. Ice algae were an important carbon source of abundant metazoan species in summer 2012, accounting for up to about $50 \%$ of the carbon demand in the pelagic copepods Calanus spp., and over $90 \%$ in the sympagic amphipod Apherusa glacialis (Kohlbach et al. 2016).

Hydrographical structures, sea-ice properties and advection patterns were major drivers of community composition. Several of these drivers were intrinsically linked to seasonal changes in both habitats, impeding a clear disentanglement of seasonal change and environmental drivers. In 2012, the sampling period extended over 9 weeks from summer to the onset of winter (Table 1). Seasonal changes were indicated by decreasing temperatures in the mixed layer (T.ML), increasing mixed layer depth (MLD) and high sea-ice concentrations (SIC) towards the end of the sampling period (Fig. 2). In the under-ice habitat, seasonal processes, such as the increased exchange of protist communities between water column and sea ice during the onset of freezing (Hardge et al. 2017b) and the seasonal downward migration of copepods (David et al. 2015) probably influenced community structure at locations I-K (Fig. 4a, c). In the epipelagic habitat, seasonal change of community composition appeared less pronounced, as the hydrographically similar earliest and latest locations B and $\mathrm{K}$ grouped closely together in the CCA (Fig. 4b, d). This indicates that seasonal change of community composition was most pronounced at the ice-water interface due to the more extreme physical changes at the surface, e.g. from melting conditions to freeze-up. 


\section{Trophic community structure}

Variability of sea-ice properties was an important driver of the taxonomic community structure in both protists and metazoans (Table 3, Fig. 4). This pattern, however, was not mirrored in the trophic structure of the communities. In all four communities, a stronger dominance of the most heterotrophic trophic group (protists: heterotrophs; metazoans: carnivores) was associated with sampling locations of the shelf-influenced and Polar regimes with low nitrate + nitrite concentrations $\left(\mathrm{NO}_{x}\right)$ (Fig. 5). Conversely, the dominance of the most heterotrophic trophic group was negatively related with $\mathrm{NO}_{x}$ in both protist communities and in epipelagic metazoans (Table 4 ). When primary production is limited by nutrient depletion, heterotrophic processes can be expected to increase in relative importance, because autotrophs and their herbivorous grazers cannot realise their full growth potential relative to their heterotrophic competitors and predators. Basedow et al. (2010) explained an increase in mean trophic levels of the zooplankton community from a bloom- to a post-bloom situation in the Barents Sea by a switch from a dominance of small herbivorous zooplankton to a dominance of carnivorous zooplankton, combined with a change in the diet of omnivorous grazers, such as Calanus spp. Our results show that similar processes take place in the central Arctic Ocean. A dominance of heterotrophic processes has been linked with nutrient limitation in several ecosystems of the Western Arctic Ocean bordering the Canada Basin, due to either hydrographical structures (e.g. shelf versus basin), or seasonal succession (Cota et al. 1996; Levinsen et al. 1999; Nielsen and Hansen 1999; Forest et al. 2014). The Canada Basin is a mostly oligotrophic environment, because nutrient input through the Bering Strait and by riverine input is used up on the shelf (Tremblay et al. 2015). In contrast, the Eurasian Basin receives substantial nutrient input through the Fram Strait, which is redistributed by the surface currents, leading to strong gradients. Because of these more intensive nutrient dynamics in the Eurasian Basin, changes in the trophic structure of the ecosystem due to changing nutrient distribution can be expected to be more pronounced. Therefore, we consider the Eurasian Basin a well-suited model system to study the interacting effects of sea-ice distribution and nutrient availability on the ecosystem of the central Arctic Ocean.

Our analysis of trophic structure faces several caveats that are founded in the quantification of protist community structure by OTUs rather than abundances or biomass, and in limited knowledge about the trophic ecology of various protist and metazoan taxa. Generally, it is difficult to relate sequence abundances of protists to cell number or biomass, because the number of target gene copies varies between protist species (Prokopowich et al. 2003; Zhu et al. 2005; Godhe et al. 2008; Egge et al. 2013). A microscopic analysis of two subsurface water samples (locations $\mathrm{C}$ and $\mathrm{H}$; Online Resource ESM3) found that diatoms constituted 3-5\% of the protist biomass, which was in agreement with the low share of diatom sequences and biomass in our study region (Roca-Martí et al. 2016; Hardge et al. 2017b). Microscopic analysis further confirmed the dominance of dinoflagellates in OTU abundances (Hardge et al. 2017b), but indicated that the relative biomass of ciliates could have been higher by a factor of 2-3 compared to the relative OTU abundance. Furthermore, we likely underestimated the abundance of haptophytes due to insufficient coverage of the 18S rRNA gene primer set used (Balzano et al. 2012; Bradley et al. 2016). In spite of these limitations, we assume that relative differences in OTU abundance patterns between environmental regimes realistically reflect the intrinsic variability of the system investigated here, because the potential bias of relative OTU abundances compared to relative abundance or biomass affected all samples equally. In our approach to analyse the trophic structure of the two protist communities we classified dinoflagellates as mixotrophs, because many dinoflagellates can switch between a photo-autotrophic and a heterotrophic mode of life. Dinoflagellates in autotrophic mode, however, are rare in Arctic oceanic ecosystems during late summer (Levinsen et al. 1999; Nielsen and Hansen 1999), and they constituted less than $0.1 \%$ of the dinoflagellate biomass in the microscopic analysis (Online Resource ESM3). Likewise, we classified Calanus copepods as herbivores, although they can prey substantially on microzooplankton (Ohman and Runge 1994; Levinsen et al. 2000; Campbell et al. 2009). Bulk stable isotope data from Calanus spp. from our sampling campaign showed that mean $\delta{ }^{15} \mathrm{~N}$ values ranged between $2.7-3.5$ and $3.0-3.8 \%$ o above the trophic baselines of ice algae and phytoplankton in C. glacialis and C. hyperboreus, respectively (Kohlbach et al. 2016). Assuming a mean $\delta^{15} \mathrm{~N}$ enrichment of 3.4\%o per trophic level (Minagawa and Wada 1984), the two most abundant Calanus copepods in our study would be considered herbivores. Yet, even a conservative approach considering Calanus spp. as omnivores would not change the general pattern of an increased dominance of carnivores in locations with low $\mathrm{NO}_{x}$ values compared to locations with high $\mathrm{NO}_{x}$ values (Fig. 5c, d).

The ecosystem investigated in this study has been characterised as a system with low primary productivity (Fernández-Méndez et al. 2015), supporting a food web that was nonetheless capable of sustaining a significant population of polar cod Boreogadus saida (David et al. 2016; Kohlbach et al. 2017). In high-Arctic ecosystems, primary productivity is usually limited to a short period in springtime, from the onset of light intrusion through sea-ice, until the available nutrient stocks are consumed to depletion (e.g. Hill et al. 2013). This springtime bloom starts with ice algae and continues in the water column under thinning sea ice, and in 
ice-free areas. During the survey period of our study, large amounts of fresh ice algal material on the seafloor indicated that an ice-algae bloom period had occurred in parts of the investigation area only shortly before our sampling (Boetius et al. 2013; Roca-Martí et al. 2016). During our sampling campaign, the food demand of abundant herbivorous grazers alone exceeded primary production of both ice algae and phytoplankton (David et al. 2015; Kohlbach et al. 2016). This suggests that in the Eurasian Basin the predominantly heterotrophic food web observed in this study was largely fuelled by an early-season ice algae production peak.

In the central Arctic Ocean ecosystem, the already existing natural dominance of heterotrophic organisms during late summer could be significantly enhanced when nutrients are further depleted. A tentative comparison of key ecosystem parameters and -functions indicates that in summer 2012 sampling locations in the more heterotrophic, $\mathrm{NO}_{x}$-poor shelf-influenced and Polar regimes were associated with considerably lower median ice algae primary production, metazoan biomass, secondary production, carbon demand, and carbon export, compared to sampling locations in the less heterotrophic, nutrient-rich Atlantic regime (Table 5). In spite of lower metazoan biomass, the median ratio of metazoan carbon demand versus primary production was twice as high in the Polar regime as in the Atlantic regime, emphasising the strong heterotrophic character of the food web in nutrient-poor conditions. In the $\mathrm{NO}_{x}$-poor regimes, a lower export flux was predominantly related to low algal production, but may have been further diminished by the high grazing pressure of heterotrophic protists, transforming potentially exported particulate carbon into dissolved carbon by respiration and excretion (Forest et al. 2014). Furthermore, low abundances of herbivorous zooplankton caused only a low flux of fast-sinking faecal pellets (Lalande et al.

Table 5 Ecological key parameters of the study area during PS80

\begin{tabular}{|c|c|c|c|c|c|c|c|}
\hline & Parameter & Unit & Shelf-influenced & Polar & Atlantic & Total & Source \\
\hline \multirow[t]{3}{*}{$\begin{array}{l}\text { Ice algae (incl. } \\
\text { melt ponds) }\end{array}$} & $\begin{array}{c}\text { Chlorophyll } a \\
\text { biomass }\end{array}$ & $\mathrm{mg} \mathrm{m}^{-3}$ & $0.29(0.24-0.51)$ & $1.05(0.40-2.54)$ & $0.43(0.36-0.50)$ & $0.57(0.30-1.38)$ & This study \\
\hline & Carbon biomass ${ }^{\mathrm{a}}$ & $\mathrm{mg} \mathrm{C} \mathrm{m}{ }^{-3}$ & $14.5(12.0-25.5)$ & $\begin{array}{c}52.5(20.0- \\
127.0)\end{array}$ & $21.5(18.0-25.0)$ & $28.5(15.0-69.0)$ & This study \\
\hline & $\begin{array}{l}\text { Primary produc- } \\
\text { tion }\end{array}$ & $\mathrm{mgC} \mathrm{m}{ }^{-2} \mathrm{~d}^{-1}$ & $\begin{array}{l}0.30 \\
(0.26-0.45)\end{array}$ & $0.65(0.38-2.05)$ & $\begin{array}{l}8.01(4.51- \\
11.50)\end{array}$ & $0.86(0.53-3.08)$ & $\begin{array}{l}\text { Fernández- } \\
\text { Méndez et al. } \\
\text { (2015) }\end{array}$ \\
\hline \multirow[t]{3}{*}{ Phytoplankton } & $\begin{array}{c}\text { Chlorophyll } a \\
\text { biomass }\end{array}$ & $\mathrm{mg} \mathrm{m}^{-3}$ & $0.26(0.22-0.29)$ & $0.21(0.15-0.26)$ & $0.17(0.14-0.20)$ & $0.19(0.15-0.23)$ & This study \\
\hline & Carbon biomass ${ }^{\mathrm{a}}$ & $\mathrm{mgC} \mathrm{m}^{-3}$ & $13.00(11-14.5)$ & $10.50(7.5-13)$ & $8.50(7-10)$ & $9.50(7.5-11.5)$ & This study \\
\hline & $\begin{array}{l}\text { Primary produc- } \\
\text { tion }\end{array}$ & $\mathrm{mg} \mathrm{C} \mathrm{m}{ }^{-2} \mathrm{~d}^{-1}$ & $\begin{array}{l}28.00(17.00- \\
\quad 44.00)\end{array}$ & $\begin{array}{l}8.50(1.88- \\
23.75)\end{array}$ & $\begin{array}{l}28.00(26.50- \\
29.50)\end{array}$ & $\begin{array}{l}18.0(4.63- \\
28.75)\end{array}$ & $\begin{array}{l}\text { Fernández- } \\
\text { Méndez et al. } \\
\text { (2015) }\end{array}$ \\
\hline \multirow[t]{4}{*}{$\begin{array}{l}\text { Under-ice meta- } \\
\text { zoans }\end{array}$} & Biomass & $\mathrm{mg} \mathrm{m}^{-2}$ & $4.40(3.86-7.11)$ & 9.93 & $\begin{array}{c}17.35(5.48- \\
16.40)\end{array}$ & $\begin{array}{c}6.72(4.10- \\
17.30)\end{array}$ & This study \\
\hline & Carbon biomass ${ }^{\mathrm{b}}$ & $\mathrm{mg} \mathrm{m}^{-2}$ & $1.76(1.54-2.84)$ & 3.97 & $6.94(2.19-6.56)$ & $2.61(1.64-6.92)$ & This study \\
\hline & $\begin{array}{l}\text { Secondary } \\
\text { Production }^{\mathrm{c}}\end{array}$ & $\mathrm{mgC} \mathrm{m}{ }^{-2} \mathrm{~d}^{-1}$ & $0.02(0.02-0.03)$ & 0.05 & $0.08(0.03-0.08)$ & $0.03(0.02-0.08)$ & This study \\
\hline & Carbon demand $^{\mathrm{d}}$ & $\mathrm{mg} \mathrm{C} \mathrm{m} \mathrm{m}^{-2} \mathrm{~d}^{-1}$ & $0.08(0.08-0.12)$ & 0.19 & $0.33(0.12-0.32)$ & $0.13(0.08-0.32)$ & This study \\
\hline \multirow[t]{4}{*}{$\begin{array}{l}\text { Epipelagic meta- } \\
\text { zoans }\end{array}$} & Biomass & $\mathrm{mg} \mathrm{m}^{-2}$ & $\begin{array}{l}1972(1463- \\
3412)\end{array}$ & $\begin{array}{l}1611(1250- \\
1738)\end{array}$ & $\begin{array}{l}3121(2876- \\
3491)\end{array}$ & $\begin{array}{l}1972(1661- \\
3121)\end{array}$ & This study \\
\hline & Carbon biomass ${ }^{\mathrm{b}}$ & $\mathrm{mg} \mathrm{m}^{-2}$ & $789(585-1365)$ & $644(500-695)$ & $\begin{array}{l}1248(1150- \\
1396)\end{array}$ & $789(664-1248)$ & This study \\
\hline & $\begin{array}{l}\text { Secondary } \\
\text { Production }^{\mathrm{c}}\end{array}$ & $\mathrm{mgC} \mathrm{m}{ }^{-2} \mathrm{~d}^{-1}$ & $\begin{array}{c}9.47(7.02- \\
16.38)\end{array}$ & $7.73(6.00-8.34$ & $\begin{array}{l}14.98(13.80- \\
16.75)\end{array}$ & $\begin{array}{c}9.47(7.97- \\
14.98)\end{array}$ & This study \\
\hline & Carbon demand ${ }^{\mathrm{d}}$ & $\mathrm{mgC} \mathrm{m}{ }^{-2} \mathrm{~d}^{-1}$ & $\begin{array}{l}37.86(28.08- \\
65.52)\end{array}$ & $\begin{array}{c}30.93(24- \\
33.36)\end{array}$ & $59.92(55.2-67)$ & $\begin{array}{l}37.86(31.88- \\
59.92)\end{array}$ & This study \\
\hline Export & Carbon flux & $\mathrm{mgC} \mathrm{m}{ }^{-2} \mathrm{~d}^{-1}$ & $40.0(27.5-45)$ & $27.5(11.3-47.5)$ & $70.0(42.5-85.0)$ & $45.0(15.0-50.0)$ & $\begin{array}{l}\text { Lalande et al. } \\
\text { (2014) }\end{array}$ \\
\hline
\end{tabular}

Values are medians; interquartile ranges are shown in parentheses

${ }^{a}$ Assuming a C:Chl ratio of 50:1 (Hansen et al. 1996)

${ }^{\mathrm{b}}$ Assuming a carbon content of $40 \%$ by dry mass (Thibault et al. 1999)

${ }^{\mathrm{c}}$ Assuming a production:biomass ratio of $1.2 \%$ (Forest et al. 2014)

${ }^{\mathrm{d}}$ Assuming a gross growth efficiency of about $\sim 25 \%$ (Forest et al. 2011) 
2014). This indicates that a potential spatial and/or temporal increase of nutrient-depleted areas in the central Arctic Ocean may be associated with profound, potentially negative, changes in key ecosystem functions.

\section{Conclusions}

Our results demonstrate that, besides hydrographical conditions, sea-ice influence can be an important driver of the taxonomic structure of protist and metazoan communities, both in the under-ice and the epipelagic habitats of the central Arctic Ocean. Nutrient concentration, however, was the single important driver of the trophic structure in these communities, showing that low-nutrient concentrations in the epipelagic and under-ice habitat of the Arctic Ocean were associated with increasing heterotrophy. Understanding how nutrient limitation enhances heterotrophy in ecosystems, and quantifying the potential impact this has on ecosystem functions, is fundamental for the development of future scenarios of the changing Arctic ecosystems. The relationships of taxonomic and trophic community structure with sea-ice properties, hydrography and nutrient concentrations presented in this snapshot of the ecosystem in the historical sea-ice minimum year 2012 may be indicative of the future central Arctic Ocean. For modelling future Arctic ecosystems, it is important to consider that taxonomic biodiversity can respond to different drivers than trophic diversity.

Acknowledgements This study was conducted under the Helmholtz Association Research Programme Polar regions And Coasts in the changing Earth System II (PACES II), Topic 1, WP 4 and is part of the Helmholtz Association Young Investigators Groups Iceflux: Ice-ecosystem carbon flux in polar oceans (VH-NG-800) and PLANKTOSENS (VH-NG-500). SUIT was developed by Wageningen Marine Research (formerly IMARES) with support from the Netherlands Ministry of EZ (Project WOT-04-009-036) and the Netherlands Polar Program (Project ALW 866.13.009). I.P. received financial support from the TRANSDRIFT project; BMBF project \#03G0833B. We would like to thank Captain Uwe Pahl and the crew of Polarstern expedition PS80 for their support in the field work. We thank Jan Andries van Franeker (IMARES) for kindly providing the Surface and Under-Ice Trawl (SUIT) and Michiel van Dorssen for technical support with work at sea. We are grateful for the support by Erika Allhusen, Christiane Lorenzen, Sandra Murawski, Kerstin Ötjen and Martina Vortkamp with laboratory analyses. We thank Karel Bakker for kindly providing the nutrient data. BAL and DK were partly funded by the Natural Sciences and Engineering Research Council of Canada Visiting Fellowships.

Author contributions HF was the main author of this paper, supervised the collection of environmental data, under-ice metazoan and epipelagic metazoan samples, and accomplished the data analyses. CD conducted laboratory analyses of under-ice metazoans. JE conducted laboratory analyses of epipelagic metazoan samples and provided Online Resources. KH provided protist community data based on OTU analysis and contributed to data analysis. DK provided size and weight data of under-ice metazoans. BAL collected and validated environmental data and provided Fig. 1. BN supervised epipelagic metazoan analysis.
E-MN provided count data of phytoplankton samples and advised on aspects of phytoplankton ecology. IP provided chlorophyll and other environmental datasets. KM initiated the study and advised on aspects of molecular-based biodiversity and ecology. All authors contributed significantly to the drafting of this research article.

Funding This study was conducted under the Helmholtz Association Research Programme Polar regions And Coasts in the changing Earth System II (PACES II), Topic 1, WP 4 and is part of the Helmholtz Association Young Investigators Groups Iceflux: Ice-ecosystem carbon flux in polar oceans (VH-NG-800) and PLANKTOSENS (VH-NG500). SUIT was developed by Wageningen Marine Research (formerly IMARES) with support from the Netherlands Ministry of EZ (Project WOT-04-009-036) and the Netherlands Polar Program (Project ALW 866.13.009). I.P. received financial support from the TRANSDRIFT project; BMBF project \#03G0833B. BAL and DK were partly funded by the Natural Sciences and Engineering Research Council of Canada Visiting Fellowships.

\section{Compliance with ethical standards}

Conflict of interest The authors declare that the research was conducted in the absence of any commercial or financial relationships that could be construed as a potential conflict of interest.

Ethical approval All applicable international, national, and institutional guidelines for the use of animals were followed. This article does not contain any studies with human participants performed by any of the authors.

\section{References}

Ardyna M, Gosselin M, Michel C, Poulin M, Tremblay J (2011) Environmental forcing of phytoplankton community structure and function in the Canadian High Arctic: contrasting oligotrophic and eutrophic regions. Mar Ecol Prog Ser 442:37-57

Arrigo KR, van Dijken GL (2011) Secular trends in Arctic Ocean net primary production. J Geophys Res 116:C09011

Arrigo KR, van Dijken GL (2015) Continued increases in Arctic Ocean primary production. Prog Oceanogr 136:60-70

Ashjian CJ, Campbell RG, Welch HE, Butler M, Van Keuren D (2003) Annual cycle in abundance, distribution, and size in relation to hydrography of important copepod species in the western Arctic Ocean. Deep Sea Res Pt I 50:1235-1261

Balzano S, Marie D, Gourvil P, Vaulot D (2012) Composition of the summer photosynthetic pico and nanoplankton communities in the Beaufort Sea assessed by T-RFLP and sequences of the 18S rRNA gene from flow cytometry sorted samples. ISME J 6:1480-1498. https://doi.org/10.1038/ismej.2011.213

Basedow SL, Tande KS, Zhou M (2010) Biovolume spectrum theories applied: spatial patterns of trophic levels within a mesozooplankton community at the polar front. J Plankton Res 32:1105-1119. https://doi.org/10.1093/plankt/fbp110

Bauch D, Torres-Valdes S, Polyakov I, Novikhin A, Dmitrenko I, McKay J, Mix A (2014) Halocline water modification and alongslope advection at the Laptev Sea continental margin. Ocean Sci 10:141-154. https://doi.org/10.5194/os-10-141-2014

Bluhm B, Gradinger R, Schnack-Schiel SB (2010) Sea ice meio- and macrofauna. In: Thomas DN, Dieckmann G (eds) Sea ice. Blackwell Publishing, Oxford, UK, pp 357-394

Bluhm BA, Gebruk AV, Gradinger R, Hopcroft RR, Huettmann F, Kosobokova KN, Sirenko BI, Weslawski JM (2011) Arctic 
marine biodiversity: asn update of species richness and examples of biodiversity change. Oceanography $24: 232-248$. https://doi. org/10.5670/oceanog.2011.75

Bluhm BA, Kosobokova KN, Carmack EC (2015) A tale of two basins: an integrated physical and biological perspective of the deep Arctic Ocean. Prog Oceanogr 139:89-121. https://doi.org/10.1016/j. pocean.2015.07.011

Boetius A, Albrecht S, Bakker K, Bienhold C, Felden J, FernándezMéndez M, Hendricks S, Katlein C, Lalande C, Krumpen T, Nicolaus M, Peeken I, Rabe B, Rogacheva A, Rybakova E, Somavilla R, Wenzhöfer F, Party RPA (2013) Export of algal biomass from the melting Arctic sea ices. Science 339:1430-1432. https://doi. org/10.1126/science. 1231346

Bokulich NA, Subramanian S, Faith JJ, Gevers D, Gordon JI, Knight R, Mills DA, Caporaso JG (2013) Quality-filtering vastly improves diversity estimates from Illumina amplicon sequencing. Nat Methods 10:57-59

Bradley IM, Pinto AJ, Guest JS (2016) Design and evaluation of Illumina MiSeq-compatible, 18S rRNA gene-specific primers for improved characterization of mixed phototrophic communities. Appl Environ Microb 82:5878-5891. https://doi.org/10.1128/ Aem.01630-16

Budge S, Wooller M, Springer A, Iverson S, McRoy C, Divoky G (2008) Tracing carbon flow in an arctic marine food web using fatty acid-stable isotope analysis. Oecologia 157:117-129

Campbell RG, Sherr EB, Ashjian CJ, Plourde S, Sherr BF, Hill V, Stockwell DA (2009) Mesozooplankton prey preference and grazing impact in the western Arctic Ocean. Deep Sea Res Pt Ii 56:1274-1289. https://doi.org/10.1016/j.dsr2.2008.10.027

Caporaso JG, Kuczynski J, Stombaugh J, Bittinger K, Bushman FD, Costello EK, Fierer N, Peña AG, Goodrich JK, Gordon JI (2010) QIIME allows analysis of high-throughput community sequencing data. Nat Methods 7:335-336

Codispoti LA, Kelly V, Thessen A, Matrai P, Suttles S, Hill V, Steele M, Light B (2013) Synthesis of primary production in the Arctic Ocean: III. Nitrate and phosphate based estimates of net community production. Prog Oceanogr 110:126-150. https://doi. org/10.1016/j.pocean.2012.11.006

Cota GF, Pomeroy LR, Harrison WG, Jones EP, Peters F, Sheldon WM, Weingartner TR (1996) Nutrients, primary production and microbial heterotrophy in the southeastern Chukchi Sea: Arctic summer nutrient depletion and heterotrophy. Mar Ecol Prog Ser 135:247-258. https://doi.org/10.3354/meps135247

David C, Lange B, Rabe B, Flores H (2015) Community structure of under-ice fauna in the Eurasian central Arctic Ocean in relation to environmental properties of sea-ice habitats. Mar Ecol Prog Ser 522:15-32. https://doi.org/10.3354/meps11156

David C, Lange B, Krumpen T, Schaafsma F, van Franeker JA, Flores $\mathrm{H}$ (2016) Under-ice distribution of polar cod Boreogadus saida in the central Arctic Ocean and their association with sea-ice habitat properties. Polar Biol 39:981-994. https://doi.org/10.1007/s0030 0-015-1774-0

Edler L (1979) Recommendations on methods for marine biological studies in the Baltic Sea. Phytoplankton and chlorophyll. Baltic Marine Biologists Working Group 9

Egge E, Bittner L, Andersen T, Audic S, de Vargas C, Edvardsen B (2013) 454 pyrosequencing to describe microbial eukaryotic community composition, diversity and relative abundance: a test for marine haptophytes. PLoS ONE 8:e74371

Ehrlich J (2015) Diversity and distribution of high-Arctic zooplankton in the Eurasian Basin in late summer 2012. Master Thesis. Centrum für Naturkunde (CeNaK), Hamburg

Evans CA, O'Reilly JE, Thomas JP (1987) Part 1, A Handbook for the measurement of Chlorophyll a in netplankton and nannoplankton. In: Evans CA, O'Reilly JE, Thomas JP (eds) A Handbook for the measurement of Chlorophyll a and primary production. BIO-MASS scientic series. Texas A \& M University, College Station, Tx, pp 3-46

Falk-Petersen S, Gatten RR, Sargent JR, Hopkins CCE (1981) Ecological investigations on the zooplankton community in Balsfjorden, Northern Norway: seasonal changes in the lipid class composition of Meganyctiphanes norvegica (M. Sars), Thysanoessa raschii (M. Sars), and T. inermis (Krøyer). J Exp Mar Biol Ecol 54:209-224. https://doi.org/10.1016/00220981(81)90158-1

Fernández-Méndez M, Katlein C, Rabe B, Nicolaus M, Peeken I, Bakker K, Flores H, Boetius A (2015) Photosynthetic production in the central Arctic Ocean during the record sea-ice minimum in 2012. Biogeosciences 12:3525-3549. https://doi.org/10.5194/ bg-12-3525-2015

Flores H, van Franeker JA, Siegel V, Haraldsson M, Strass VH, Meesters EHWG, Bathmann U, Wolff WJ (2012) The association of Antarctic krill Euphausia superba with the under-ice habitat. PLoS ONE 7:e31775. https://doi.org/10.1371/journal.pone.00317 75

Forest A, Tremblay JE, Gratton Y, Martin J, Gagnon J, Darnis G, Sampei M, Fortier L, Ardyna M, Gosselin M, Hattori H, Nguyen D, Maranger R, Vaque D, Marrase C, Pedros-Alio C, Sallon A, Michel C, Kellogg C, Deming J, Shadwick E, Thomas H, Link H, Archambault P, Piepenburg D (2011) Biogenic carbon flows through the planktonic food web of the Amundsen Gulf (Arctic Ocean): a synthesis of field measurements and inverse modeling analyses. Prog Oceanogr 91:410-436. https://doi.org/10.1016/j. pocean.2011.05.002

Forest A, Coupel P, Else B, Nahavandian S, Lansard B, Raimbault P, Papakyriakou T, Gratton Y, Fortier L, Tremblay JE, Babin M (2014) Synoptic evaluation of carbon cycling in the Beaufort Sea during summer: contrasting river inputs, ecosystem metabolism and air-sea $\mathrm{CO}_{2}$ fluxes. Biogeosciences 11:2827-2856. https://doi. org/10.5194/bg-11-2827-2014

Fujiwara A, Hirawake T, Suzuki K, Imai I, Saitoh SI (2014) Timing of sea ice retreat can alter phytoplankton community structure in the western Arctic Ocean. Biogeosciences 11:1705-1716. https://doi. org/10.5194/bg-11-1705-2014

Godhe A, Asplund ME, Harnstrom K, Saravanan V, Tyagi A, Karunasagar I (2008) Quantification of diatom and dinoflagellate biomasses in coastal marine seawater samples by Real-Time PCR. Appl Environ Microb 74:7174-7182. https://doi.org/10.1128/ Aem.01298-08

Gosselin M, Levasseur M, Wheeler PA, Horner RA, Booth BC (1997) New measurements of phytoplankton and ice algal production in the Arctic Ocean. Deep Sea Res II (Top Stud Oceanogr) 44:1623-1644

Gradinger RR, Bluhm BA (2004) In-situ observations on the distribution and behavior of amphipods and Arctic cod (Boreogadus saida) under the sea ice of the High Arctic Canada Basin. Polar Biol 27:595-603. https://doi.org/10.1007/s00300-004-0630-4

Hansen B, Christiansen S, Pedersen G (1996) Plankton dynamics in the marginal ice zone of the central Barents Sea during spring: carbon flow and structure of the grazer food chain. Polar Biol 16:115-128

Hardge K, Peeken I, Neuhaus S, Krumpen T, Stoeck T, Metfies K (2017) Sea ice origin and sea ice retreat as possible drivers of variability in Arctic marine protist composition. Mar Ecol Prog Ser 571:43-57. https://doi.org/10.3354/meps12134

Hardge K, Peeken I, Neuhaus S, Lange BA, Stock A, Stoeck T, Weinisch L, Metfies K (2017) The importance of sea ice for exchange of habitat-specific protist communities in the Central Arctic Ocean. J Mar Syst 165:124-138. https://doi.org/10.1016/j.jmars ys.2016.10.004

Hill VJ, Matrai PA, Olson E, Suttles S, Steele M, Codispoti LA, Zimmerman RC (2013) Synthesis of integrated primary production in the Arctic Ocean: II. In situ and remotely sensed estimates. 
Prog Oceanogr 110:107-125. https://doi.org/10.1016/j.pocea n.2012.11.005

Hop H, Poltermann M, Lonne OJ, Falk-Petersen S, Korsnes R, Budgell WP (2000) Ice amphipod distribution relative to ice density and under-ice topography in the northern Barents Sea. Polar Biol 23:357-367. https://doi.org/10.1007/s003000050456

Hunt BPV, Nelson RJ, Williams B, McLaughlin FA, Young KV, Brown KA, Vagle S, Carmack EC (2014) Zooplankton community structure and dynamics in the Arctic Canada Basin during a period of intense environmental change (2004-2009). J Geophys ResOceans 119:2518-2538. https://doi.org/10.1002/2013JC009156

IPCC (2014) Climate change 2014: impacts, adaptation, and vulnerability. Part B: regional aspects. Contribution of working group II to the fifth assessment. Report of the intergovernmental panel on climate change, Cambridge, New York

Kattner G, Lobbes JM, Fitznar HP, Engbrodt R, Nothig EM, Lara RJ (1999) Tracing dissolved organic substances and nutrients from the Lena River through Laptev Sea (Arctic). Mar Chem 65:25-39. https://doi.org/10.1016/S0304-4203(99)00008-0

Kilias E, Wolf C, Noethig E-M, Peeken I, Metfies K (2013) Prostist distribution in the western Fram Strait in summer 2010 based on 454-pyrosequencing of 18S rDNA. J Phycol 49:996-1010. https ://doi.org/10.1111/jpy.12109

Kohlbach D, Graeve M, Lange B, David C, Peeken I, Flores H (2016) The importance of ice algae-produced carbon in the central Arctic Ocean ecosystem: food web relationships revealed by lipid and stable isotope analyses. Limnol Oceanogr 61:2027-2044. https:// doi.org/10.1002/lno.10351

Kohlbach D, Schaafsma FL, Graeve M, Lebreton B, Lange BA, David C, Vortkamp M, Flores H (2017) Strong linkage of polar cod (Boreogadus saida) to sea ice algae-produced carbon: evidence from stomach content, fatty acid and stable isotope analyses. Prog Oceanogr 152:62-74. https://doi.org/10.1016/j.pocea n.2017.02.003

Kosobokova K, Hirche HJ (2000) Zooplankton distribution across the Lomonosov Ridge, Arctic Ocean: species inventory, biomass and vertical structure. Deep Sea Res Pt I 47:2029-2060. https://doi. org/10.1016/S0967-0637(00)00015-7

Kraft A, Nöthig E-M, Bauerfeind E, Wildish DJ, Pohle GW, Bathmann UV, Beszczynska-Moller A, Klages M (2013) First evidence of reproductive success in a southern invader indicates possible community shifts among Arctic zooplankton. Mar Ecol Prog Ser 493:291-296. https://doi.org/10.3354/meps 10507

Kwok R, Rothrock D (2009) Decline in Arctic sea ice thickness from submarine and ICESat records: 1958-2008. Geophys Res Lett 36:L15501

Lalande C, Nöthig EM, Somavilla R, Bauerfeind E, Shevchenko V, Okolodkov Y (2014) Variability in under-ice export fluxes of biogenic matter in the Arctic Ocean. Glob Biogeochem Cycle 28:571-583

Lange BA, Katlein C, Nicolaus M, Peeken I, Flores H (2016J) Sea ice algae chlorophyll a concentrations derived from under-ice spectral radiation profiling platforms. J Geophys Res 121:8511-8534. https://doi.org/10.1002/2016JC011991

Laxon SW, Giles KA, Ridout AL, Wingham DJ, Willatt R, Cullen R, Kwok R, Schweiger A, Zhang J, Haas C (2013) CryoSat-2 estimates of Arctic sea ice thickness and volume. Geophys Res Lett 40:732-737

Levinsen H, Nielsen TG, Hansen BW (1999) Plankton community structure and carbon cycling on the western coast of Greenland during the stratified summer situation. II. Heterotrophic dinoflagellates and ciliates. Aquat Microb Ecol 16:217-232. https://doi. org/10.3354/ame016217

Levinsen H, Turner JT, Nielsen TG, Hansen BW (2000) On the trophic coupling between protists and copepods in arctic marine ecosystems. Mar Ecol Prog Ser 204:65-77. https://doi. org/10.3354/meps204065

McCullagh P, Nelder JA (1989) Generalized linear models, 2nd edn. Chapman \& Hall, New York

Metfies K, von Appen W-J, Kilias E, Nicolaus A, Nöthig E-M (2016) Biogeography and photosynthetic biomass of arctic marine picoeukaroytes during summer of the record sea ice minimum 2012. PLoS ONE 11:e0148512

Minagawa M, Wada E (1984) Stepwise enrichment of $15 \mathrm{~N}$ along food chains: further evidence and the relation between $\delta 15 \mathrm{~N}$ and animal age. Geochim Cosmochim Acta 48:1135-1140

Mumm N, Auel H, Hanssen H, Hagen W, Richter C, Hirche HJ (1998) Breaking the ice: large-scale distribution of mesozooplankton after a decade of Arctic and transpolar cruises. Polar Biol 20:189197. https://doi.org/10.1007/s003000050295

Nicolaus M, Katlein C, Maslanik J, Hendricks S (2012g) Changes in Arctic sea ice result in increasing light transmittance and absorption. Geophys Res Lett 39:L24501. https://doi.org/10.1029/2012g 1053738

Nielsen TG, Hansen BW (1999) Plankton community structure and carbon cycling on the western coast of Greenland during the stratified summer situation. I. Hydrography, phytoplankton and bacterioplankton. Aquat Microb Ecol 16:205-216. https://doi. org/10.3354/ame016205

Nöthig E-M, Bracher A, Engel A, Metfies K, Niehoff B, Peeken I, Bauerfeind E, Cherkasheva A, Gäbler-Schwarz S, Hardge K (2015) Summertime plankton ecology in Fram Strait-a compilation of long-and short-term observations. Polar Res 34:23349

Ohman MD, Runge JA (1994) Sustained fecundity when phytoplankton resources are in short supply-omnivory by Calanus finmarchicus in the Gulf of St. Lawrence. Limnol Oceanogr 39:21-36

Oksanen J, Blanchett FG, Kindt R, Legendre P, Minchin PR, O'Hara RB, Simpson GL, Solymos PM, Stevens MHH, Wagner H (2013) Vegan: community ecology package version 2.0-10. R Foundation for Statistical Computing

Parkinson CL, Comiso JC (2013) On the 2012 record low Arctic sea ice cover: combined impact of preconditioning and an August storm. Geophys Res Lett 40:1356-1361. https://doi.org/10.1002/ $\operatorname{grl} .50349$

Poltermann M, Hop H, Falk-Petersen S (2000) Life under Arctic sea ice-reproduction strategies of two sympagic (ice-associated) amphipod species, Gammarus wilkitzkii and Apherusa glacialis. Mar Biol 136:913-920. https://doi.org/10.1007/s002270000307

Prokopowich CD, Gregory TR, Crease TJ (2003) The correlation between rDNA copy number and genome size in eukaryotes. Genome 46:48-50. https://doi.org/10.1139/G02-103

$\mathrm{R}$ Core Team (2017) R: a language and environment for statistical computing. R Foundation for Statistical Computing, Vienna, Austria. https://www.R-project.org/

Rabe B, Wisotzki A, Rettig S, Somavilla Cabrillo R, Sander H (2012) Physical oceanography during POLARSTERN cruise ARKXXVII/3 (IceArc) PANGEA. Alfred Wegener Institute, Helmholtz Center for Polar and Marine Research, Bremerhaven. https://doi. org/10.1594/PANGAEA.802904

Roca-Martí M, Puigcorbé V, Rutgers van der Loeff MM, Katlein C, Fernández-Méndez M, Peeken I, Masqué P (2016) Carbon export fluxes and export efficiency in the central Arctic during the record sea-ice minimum in 2012: a joint $234 \mathrm{Th} / 238 \mathrm{U}$ and 210Po/210Pb study. J Geophys Res 121:5030-5049. https://doi. org/10.1002/2016JC011816

Rudels B, Schauer U, Björk G, Korhonen M, Pisarev S, Rabe B, Wisotzki A (2013) Observations of water masses and circulation with focus on the Eurasian Basin of the Arctic Ocean from the 1990s to the late 2000s. Ocean Sci 9:147-169. https://doi. org/10.5194/os-9-147-2013 
Sakshaug E (2004) Primary and secondary production in the Arctic Seas. In: Stein R, MacDonald RW (eds) The organic carbon cycle in the Arctic Ocean. Springer, Berlin, pp 57-81

Serreze MC, Holland MM, Stroeve J (2007) Perspectives on the Arctic's shrinking sea-ice cover. Science 315:1533-1536

Shaw W, Stanton T, McPhee M, Morison J, Martinson D (2009) Role of the upper ocean in the energy budget of Arctic sea ice during SHEBA. J Geophys Res 114:C06012

Simmonds I (2015) Comparing and contrasting the behaviour of Arctic and Antarctic sea ice over the 35 year period 1979-2013. Ann Glaciol 56:18-28

Søreide JE, Leu E, Berge J, Graeve M, Falk-Petersen S (2010) Timing of blooms, algal food quality and Calanus glacialis reproduction and growth in a changing Arctic. Glob Chang Biol 16:3154-3163. https://doi.org/10.1111/j.1365-2486.2010.02175.x

Spreen G, Kaleschke L, Heygster G (2008) Sea ice remote sensing using AMSR-E 89-GHz channels. J Geophys Res 113:C02S03

Stoeck T, Bass D, Nebel M, Christen R, Jones MDM, Breiner HW, Richards TA (2010) Multiple marker parallel tag environmental DNA sequencing reveals a highly complex eukaryotic community in marine anoxic water. Mol Ecol 19:21-31. https://doi. org/10.1111/j.1365-294X.2009.04480.x

Stroeve JC, Kattsov V, Barrett A, Serreze M, Pavlova T, Holland M, Meier WN (2012g) Trends in Arctic sea ice extent from CMIP5, CMIP3 and observations. Geophys Res Lett 39:L16502. https:// doi.org/10.1029/2012gl052676

Thibault D, Head EJH, Wheeler PA (1999) Mesozooplankton in the Arctic Ocean in summer. Deep Sea Res Pt I 46:1391-1415. https ://doi.org/10.1016/S0967-0637(99)00009-6

Tremblay J-É, Anderson LG, Matrai P, Coupel P, Bélanger S, Michel C, Reigstad M (2015) Global and regional drivers of nutrient supply, primary production and $\mathrm{CO}_{2}$ drawdown in the changing Arctic Ocean. Prog Oceanogr 139:171-196. https://doi.org/10.1016/j. pocean.2015.08.009

van Franeker JA, Flores H, Van Dorssen M (2009) The Surface and Under-Ice Trawl (SUIT). In: Flores H (ed) Frozen Desert Alivethe role of sea ice for pelagic macrofauna and its predators. $\mathrm{PhD}$ thesis. University of Groningen, Groningen, pp 181-188
Vergin KL, Beszteri B, Monier A, Thrash JC, Temperton B, Treusch AH, Kilpert F, Worden AZ, Giovannoni SJ (2013) High-resolution SAR11 ecotype dynamics at the Bermuda Atlantic time-series study site by phylogenetic placement of pyrosequences. ISME J 7:1322-1332

Wang M, Overland JE (2009) A sea ice free summer Arctic within 30 years? Geophys Res Lett 36:L07502

Wang SW, Budge SM, Iken K, Gradinger RR, Springer AM, Wooller MJ (2015) Importance of sympagic production to Bering Sea zooplankton as revealed from fatty acid-carbon stable isotope analyses. Mar Ecol Prog Ser 518:31-50

Wassmann P (2011) Arctic marine ecosystems in an era of rapid climate change. Prog Oceanogr 90:1-17. https://doi.org/10.1016/j. pocean.2011.02.002

Wassmann P, Duarte CM, Agusti S, Sejr MK (2011) Footprints of climate change in the Arctic marine ecosystem. Glob Chang Biol 17:1235-1249. https://doi.org/10.1111/j.1365-2486.2010.02311.x

Wassmann P, Kosobokova KN, Slagstad D, Drinkwater KF, Hopcroft RR, Moore SE, Ellingsen I, Nelson RJ, Carmack E, Popova E, Berge J (2015) The contiguous domains of Arctic Ocean advection: trails of life and death. Prog Oceanogr 139:42-65. https:// doi.org/10.1016/j.pocean.2015.06.011

Yun MS, Whitledge TE, Stockwell D, Son SH, Lee JH, Park JW, Lee DB, Park J, Lee SH (2016) Primary production in the Chukchi Sea with potential effects of freshwater content. Biogeosciences 13:737-749

Zhu F, Massana R, Not F, Marie D, Vaulot D (2005) Mapping of picoeucaryotes in marine ecosystems with quantitative PCR of the 18S rRNA gene. FEMS Microbiol Ecol 52:79-92. https://doi. org/10.1016/j.femsec.2004.10.006

Publisher's Note Springer Nature remains neutral with regard to jurisdictional claims in published maps and institutional affiliations. 